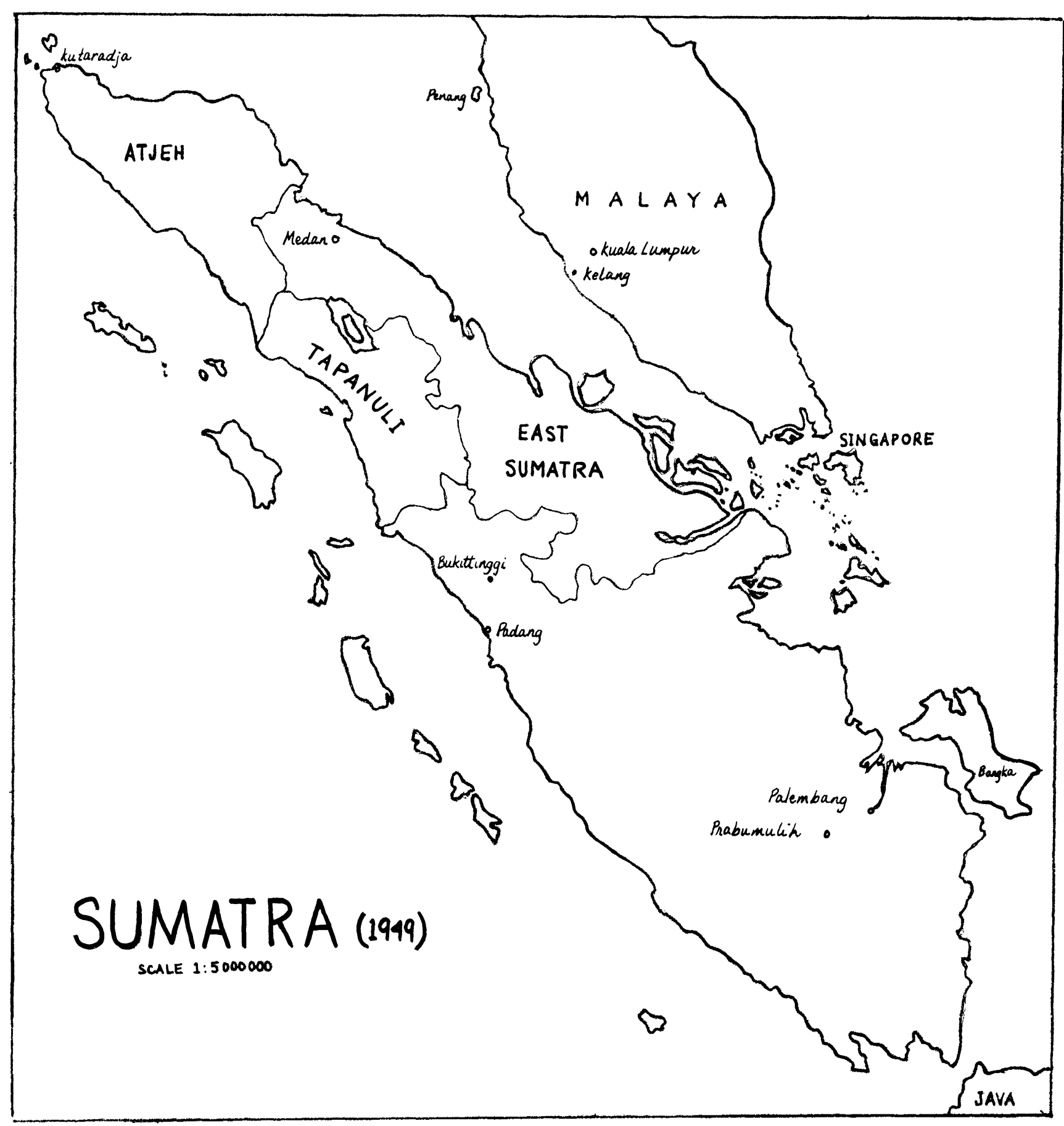




\title{
WHAT WAS THE "SOCIAL REVOLUTION OF 1946" IN EAST SUMATRA?
}

\author{
H. Mohammed Said* \\ Translated by Benedict Anderson and Toenggoel Siagian**
}

\begin{abstract}
When foreign scholars anxious to deepen their understanding of the history of the Indonesian Revolution came to me in Medan while collecting data for their theses or other research projects, they usually asked me what I knew about the "social revolution" in East Sumatra. To most such questions I give no answers since I was not directly or even indirectly involved in that event. In mid-February 1946 I was sent on a mission to Djakarta, traveling overland through Bukittinggi and Prabumulih. Only in June did I return to Medan.
\end{abstract}

When I arrived in Djakarta in the middle of March, after about a month on the road, I learned that the so-called "social revolution" had broken out. In fact the first I heard of it was from Prime Minister Sutan Sjahrir when he received me. Right off, before I could even sit down, he began questioning me as if $I$ were a prime mover in it.

Quite frankly, I stared at him dumbfounded. Someone here in Djakarta knew what was happening in my own backyard even before I did. Sjahrir was then launching his diplomatic offensive to prove that "everything is running we11" in Indonesia. So he was upset and disappointed!

In fact, however, we should not be surprised that an event of this kind took place in East Sumatra or in any other area in which the Dutch rule was extended through a system of autonomous domains, sultanates, principalities or whatever name was ever given to the structure of inlandse bestuur [native rule] or indirect bestuur [indirect rule]. Turned into "chisels" by the Dutch, and thereby developing

* H. Mohammed Said is a historian. His best known works are Atjeh Sepandjang Abad and Si Singamangaradja; among his other books the main one is 40 Hari Pendudukan Inggeris. In 1947 he set up the daily Waspada in Medan after being actively involved with other newspapers before that date. In the 1950's he was active in the PNI (and was once General Chairman for North Sumatra) and also in the PWI (Indonesian Journalists' Union).

** Translators' note: The original Indonesian text of this article appeared serially in the Djakarta newspaper Merdeka in February and March, 1972. Some minor liberties have been taken with the translation to make for smoother reading in English. The original text is liberally sprinkled with Dutch and English words, in a manner very typical of educated men of the author's generation. In the case of Dutch words, they have been left in the text with a translation in brackets, to give more of the tlavor of the writing. In addition, some explanatory footnotes have been added by the translators where it seemed they might assist the non-specialist reader. 
vested interests ${ }^{l}$ of their own, these rulers were separated from the people by a wide gulf. It would have been very strange if the rulers had been pleased with a 180 degree turnabout in political relations, and if the people had had confidence in their goodwill and sincerity.

Naturally there were some exceptions, places where such a wide gulf between ruler and ruled had no serious consequences. But even there it was a matter of degree! Atjeh, for example, a region with a rich history of resistance to Dutch colonialism, was one such exception, with the result that the "Tjumbok Affair" or the "People's Revolution of December ' 45 " was confined to selected targets. It is genera11y known that many of the rulers there understood that they were rulers to serve not the Dutch but the people. Nonetheless, the fact that the notable figure of Teuku Nja' Arif, Republican Resident of Atjeh, had to be exiled to Takeungon and died there, as did Tengku Radja Sulung, ruler of Kuala Simpang, the first man to lead the raising of the Red and White flag in his area, and to merge his region into the territory of the Republic by swearing loyalty to her, seems to show that excesses could not be avoided. 2

In Tapanuli there were also leaders with the title of radja, and even patuan, corresponding to the title of dipertuan in East Sumatra. Here, however, the Dutch had already instituted direct rule (rechtsstreeks bestuursgebied) before they understood that the "autonomous rule" structure, as effected in East Sumatra and Atjeh, could more efficiently achieve their main aims of divide and rule and colonial exploitation. Above all, Batak family law in Tapanuli, which demanded continuous harmony by virtue of the requirements of local adat (i.e., Dalihan $\mathrm{Na}$ Tolu), obliged all parties (radja, kahanggi, anak boru/mora) ${ }^{3}$ to support and complement each other. As a result the gulf (gap) that

1. The text has the English words "vested interest." Here, and in many other places, the author somewhat anachronistically uses phrases which only became part of the Indonesian political vocabulary long after the events he describes. Djakarta and Medan slang are occasionally employed for literary effect.

2. Teuku Nja' Arif, sagi-chief of the XXVI Mukims near Kutaradja, was a leading member of the uleëbalang, the Atjehnese ruling class. He was graduated from the OSVIA (Training School for Native Administrators), and later became the bestknown Atjehnese leader of the pre-war era. He sat on the Volksraad until 1931. During the Japanese period, he became top adviser to the Japanese administration in Atjeh, serving for a time as gunchō (controleur) of Kutaradja. When the Atjeh Residency Advisory Council was set up in November 1943, he was elected chairman; and when in May 1945 an All-Sumatran Advisory Council was appointed, he was chosen as one of its vice-chairmen. He was also honored by an invitation to visit Japan. In October 1945 he was named first Republican Resident of Atjeh, but fell from power during the "socia! revolution" of January 1946. He died of diabetes on Apri1 6, 1946 while under detention in the remote hill-town of Takeungon. (See A. J. Piekaar, Atjèh en de oorlog met Japan [The Hague/Bandung: van Hoeve, 1949], pp. 11-12, 15, 194, 205, 214, 220-21, 244 and 250.) Tengku Radja Sulung was the uleëbalang of Kedjuruan Muda near Kuala Simpang, Southeast Atjeh. He too was made gunchō by the Japanese (for Kuala Simpang) and sat on the Atjeh Residency Advisory Council. Like Teuku $\mathrm{Nja}$ ' Arif he was regarded as a nationalist and was somewhat distrusted by the Dutch. (See ibid., pp. 53-54, 194 and 221.)

3. Radja--chief; kahanggi--members of collateral branches of a chiefly lineage; anak boru--wife-receiving group, in Batak adat; nora--wife-giving group. 


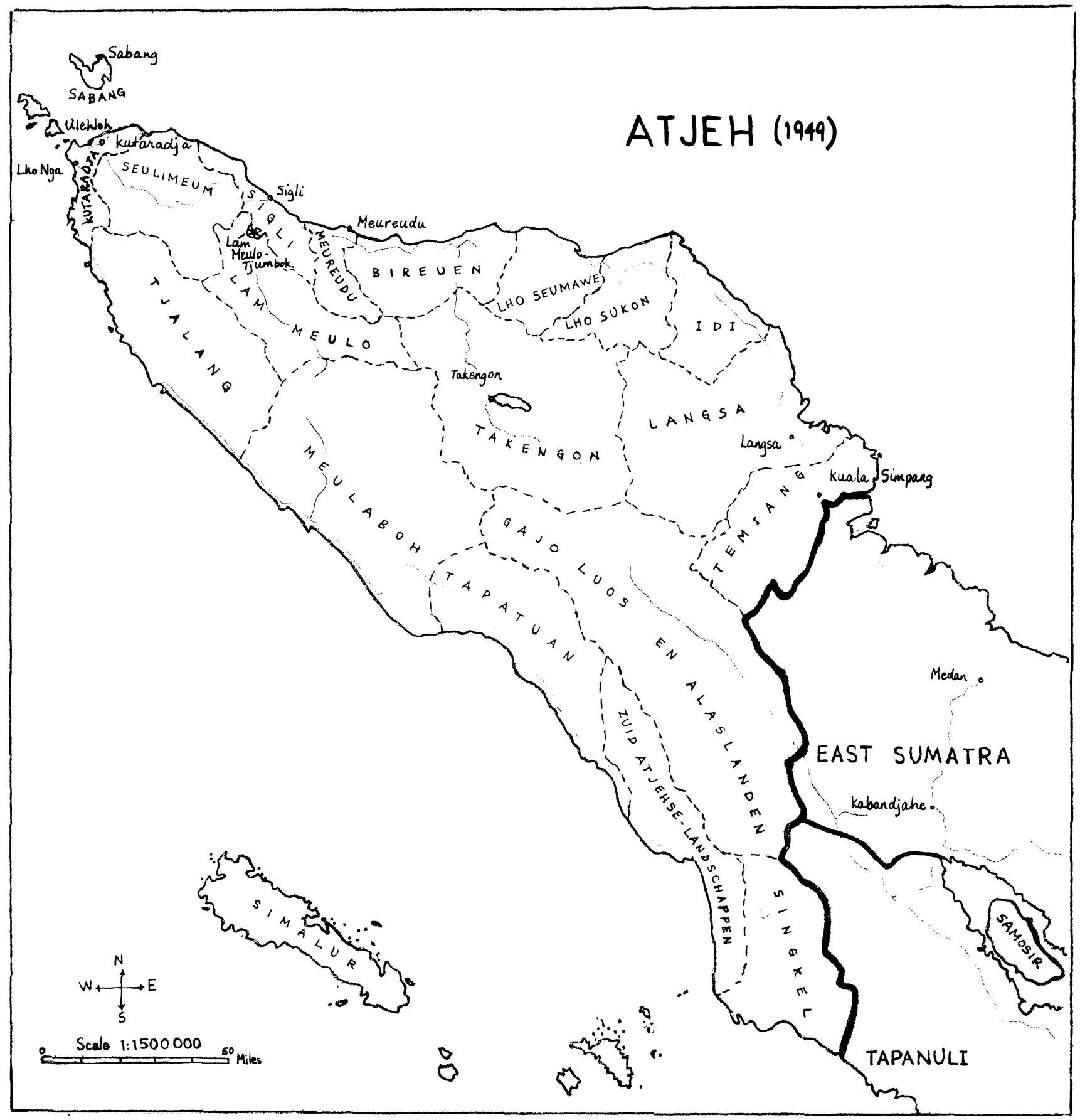




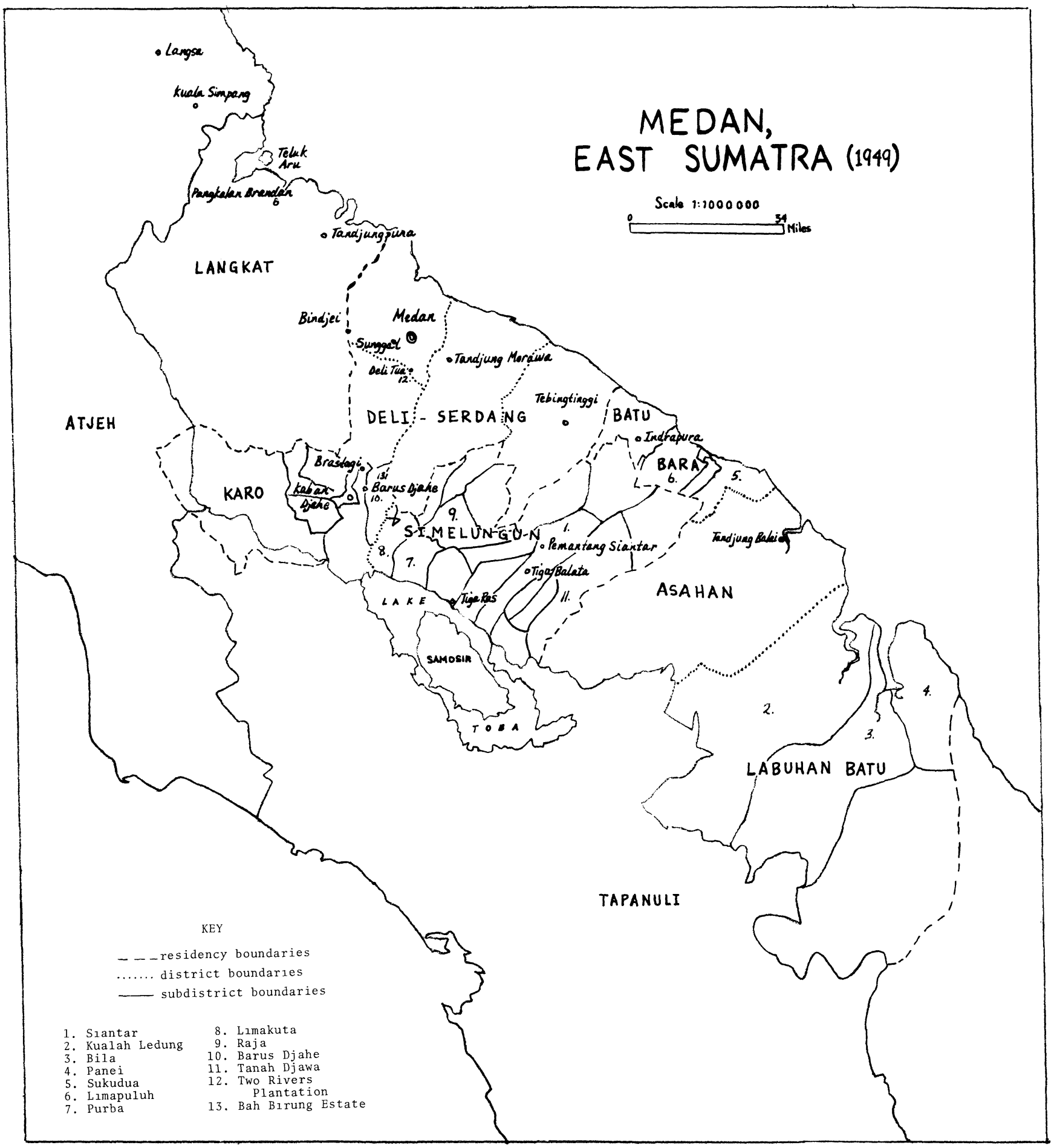


the Dutch wished to dig within so homogeneous a society could easily be closed by the development of adat, in a situation where indirect rule did not exist. But in East Sumatra, which for the most part was inhabited by native Batak (Karo, Simelungun, Hulu Asahan, etc.), the system of "autonomous rule" exalted the position of the rulers by various types of prerogatives, and drasticaliy reduced the role of the Dalihan Na Tolu. And since in East Sumatra many of the radja were not legitimate heirs but were outsiders (newcomers) or traitors to their own kin, the gulf dug by the Dutch could never be filled in.

\section{A "F1ash Back"}

Of a total of about 250 radja, great and small, developed by the Dutch outside Java, there were about 25 in East Sumatra. Their constitutional and administrative position was the same in the eyes of the Dutch authorities, but in terms of protocol they were treated very differently. Thus there were some radja with the title of Sultan who could show off their enormous wealth à la Nizam of Hyderabad, derived from "royalties" on BPM concessions, such as Langkat, or from tobacco corporations, such as Deli. These sultans were honored and were free to hold elaborate celebrations and festivities to which they could invite Dutch bigwigs and foreign consuls. On the other hand, there were radja with salaries of only a few hundred rupiah, who could only meet expenses from a side income derived from adat property. These rulers were treated by the Dutch as no better than secretaries: if even a low-level Dutch official summoned one to his office, he would hurry to obey the summons.

For the people, however, it made no difference whether they were under a rich radja or a poor one, for all these radja were turned into "chisels" by the Dutch to squeeze everything they could out of the people's physical resources, particularly with respect to taxes and corvée labor. In areas directly under Dutch administration, not much in the way of taxes could be gleaned from the common people. But in the rulers' areas, not even the lowliest person in the remotest jungle areas could elude the radja's eyes. In Dutch-administered areas corvere labor had long been abolished, while in the radja's areas, on the contrary, it was rather intensively practiced. Worse still, corvée was of many types. There was corvée of an age-old customary type. There was corve purely for the personal needs of the ruler. And, if it was considered necessary by the Dutch authorities, corvée duties could always be hatched by decree of the local ruler (zelfbestuurbesiuit), for example the organization of the Saro system in Simelungun, which was felt as a pretty heavy burden by the people.

The burden of all this suffering was by no means wholly attributed by the people to Dutch oppression, since in the main they had to deal only with the radja. That the people often regarded the radja as their oppressor can be seen from the complaints they forwarded directly to the Dutch authorities. On their side, the Dutch handled these complaints very seriously and with much compassion, not only to check on the real effects of the claws of colonialism, protected on the knees of the radja, but also to arouse a popular belief that arbitrary tyranny was the fault not of the Dutch but of the radja. It depended on the circumstances whether it was advantageous or not to ease the suffering of the people; it depended on the situation whether or not to sustain their pressure on the radja to continue as their "chisels." 
In the agricultural sector, from the very beginning of Dutch penetration of East Sumatra in 1863, the radja had been destroying the indigenous cultivations which had long been established. Concession hunters (first Dutch, then later English, German, Belgian, Polish, Russian, American, even Japanese adventurers) were given the opportunity to make use of as many thousands of hectares as they wanted, virtually for free and with minimal conditions, to open up tobacco, coffee and pepper plantations. These "Santa Claus" clearance sales involved lands being worked by the people, without their consent and in total conflict with adat law. According to this 1 aw (primarily in Deli, inhabited mainly by Karo), the people's land could not be taken from them without their consent or that of the gemeenschap or village community involved.

In that period, some of the smaller rauja, with the titles of datu or kedjuruan, from the start strongly opposed the penetration of the Dutch and their investments. The territories of these little radja, mainly Sunggal, largely occupied by Karo people, were in the sphere of influence of the Sultanate of Deli. Although they thought of themselves as independent, yet the geographical position of Deli, dominating the seaboard and the harbor, made them oppose the Sultan of Deli's unilateral policy of permitting the Dutch to enter and selling off the people's land. Furthermore, from the political angle, they felt it was extremely dangerous to ignore the factor of Atjeh, which was then in conflict with the Dutch and claimed De1i and the rest of East Sumatra as part of Atjeh. On the economic side, free trade with Penang (a British colony) was regarded as more "desirable" and "favorable." But after some years, the Sultan came to share the profits obtained from the concessions, and the problem of the people's land being grabbed by the concessionaires was ignored. The peasants, of whom there were large numbers, eventually chose the path of violence and under the leadership of three Datuks of Sunggal (Datuk Ketjil, Datuk Djalil, and Sulung Laut), whom they fully supported, they launched in 1872 a bitter armed insurrection. Only after seven months of violence did the Dutch manage to put the insurrection down, but not before huge reinforcements had to be brought from Djakarta. This rebellion should be inscribed in the pages of our national history of resistance to Dutch colonialism, since it is based on historical facts. It has already been recorded in the report of a Dutch writer who was in the war, using information he received first hand, that the rebellion (the "Batak War") was to kick out the Dutch."

\section{The Effect of Huge Investments}

The consequences of the war were pretty serious. Villages and fields were destroyed. The local people's economic activities were paralyzed, as is demonstrated by the fact that right after the resistance was broken, no peasants went to their dry-rice fields any more. That year Deli was hit by famine, and many lives would have been lost llad not the ruler, on lutch insistence, hurriedly produced from his own pocket a large sum to import rice from Penang. This is a historical fact! But this bitter experience did not induce the Dutch to hesitate in constantly pressuring the Sultan to give Dutch investments priority and preference above all else. The edict of the ruler was

4. See "De Expeditie naar Deli," Indisch Militair Tijdschrift, No. 7 \& 8 (1874), pp. 337-359. 
pronounced: the people were forbidden to grow tobacco because it had been made a Dutch monopoly, even though tobacco was a source of the local people's livelihood along with rice and pepper (discussed by Prof. K. Pelzer of Yale University in connection with the endemic landhunger in East Sumatra).

In the face of this oppression, the people evidently did not cease their anti-Dutch activity. Although threatened with destitution, they refused to offer their services as plantation labor (selling food, building materials, etc.), so that the Dutch were forced to make the decision not to employ a local work-force, but rather to bring one in from outside. In Malaya, the work-force of the tin mines was already largely Chinese. But the Dutch found a way to entice them to Deli by offering higher wages. When the British entrepreneurs understood that their best workers were being drawn away, their government banned further movement, and so the Dutch took the initiative to bring in Chinese workers from Canton, Swatow, Amoy and elsewhere, without investigating in advance whether these singkeh ${ }^{5}$ were criminals or not. Within a short space of time, these Chinese newcomers flooded East Sumatra. Furthermore, in order to develop a work-force for tasks which it was in their interests to have done by native Indonesians, the Dutch obtained extraordinary facilities to bring in transmigrants from Java by the system of werving [recruitment] and of the "coolie contract." In addition, with the cooperation of the Sultan, the Dutch opened the way for anyone to enter the area who was looking for a bite to eat or a chance to get ahead. Automatically, this meant a basic change in social structure from a homogeneous society where harmony prevailed among its Malay and Karo elements, to a quite heterogeneous society in which these people, now a minority, were overwhelmed by the tide of newcomers from outside (Minangkabau, Tapanuli, Atjeh, Java, Sunda, Bojan, Sulawesi, Malukus, Bandjar, etc.) who competed with one another and sought their fortunes in an area which suddenly became known we11known as The Dollar Country--De1i; this not counting the influx of Keling (Indians) and people from other parts of Asia, indeed also Europeans and Japanese who were energetic and acquired a privileged position.

While Dutch colonialism brought the inhabitants, mingled with huge numbers of immigrants, into a single sphere, it also made use of methods it found appropriate to perpetuate its power, including conspicuous class stratification and discrimination.

Immigrants living in a ruler's territory were considered his subjects and were subordinated to the ruler's jurisdiction with all the claws of the unwritten royal adat. Since they came with their own various native adat, naturally there was never any unity of perspective among the subjects except in regard to the negative aspects of the ruler. At the same time local inhabitants who became Dutch officials, even though local sons, were put under Dutch jurisdiction, and so, since they were freed from the toils of adat, their attitude to their own radja at the very least became freer by comparison with that of the indigenous population still within the ruler's legal control.

Accordingly, the prestige and authority of the radja varied from great to smal1, in the people's eyes, depending on the local situation and conditions. But it was clear that over the years the position of

5. Singkeh--pure-blooded, China-born Chinese. 
the rulers in the people's eyes as a whole declined. By the end they were often branded as indolent big shots who only knew how to have a good time, and moreover as only being able to enjoy this life thanks to the protection of the Dutch--but not forever!

When the nationalist movement penetrated to East Sumatra, and various leaders went down into society and also analyzed various Sospolek ${ }^{6}$ problems in the press and in public meetings, they found the institution of the autonomous territory a severe impediment. In 1915 they demanded that adat law be abolished or if not, at least be codified. This did not mean that they wanted to destroy the rulers in order to strengthen Dutch authority, but rather that the pressure exerted by these intermediaries hampered the development of harmony between ethnic groups and also aroused antipathy against the ruler on the part of his own people who were now no longer sovereign.

But the Dutch themselves, of course, wanted these conflicts to exist; and to defend their divide and rule tactics it was easy for them to say that they had no authority to change or abolish adat law, indeed that it was not the aim of colonialism to introduce Western ways of 1 ife.

Impediments to freedom of movement and assembly were very much felt in the rulers' domains. There was a kind of "floating mass"7 in the territories of the radja of East Sumatra and Atjeh (which indeed formed about $99 \%$ of the whole territory), since any kind of right to oppose the radja was unknown. Since adat law itself was unwritten, it was a simple matter to formulate and produce a completely semau gee ${ }^{8}$ type of legal code including provisions aimed at obstructing the people or anyone else from carrying on political activities (naturally after being told to "hatch" it by some assistant resident or controleur). On the basis of this adat, even closed meetings could easily be banned or broken up, and leaders who wished to visit the villages could easily be forbidden to do so or be ousted from the area, without the need of any regulation such as passenstelsel [pass-laws].

\section{$\underline{\text { Prologue }}$}

The British were at their wits' end when, in the middle of August 1945, the Japanese suddenly surrendered and Indonesia proclaimed her independence. To prevent the development of what they called a "vacuum," the British assigned to their own enemies, the Japanese, the responsibility for ensuring security in. Indonesia and sternly forbade them to help the establishment of the Republic.

At the end of August, the two Sumatran representatives attending the session of the Committee for the Preparation of the Independence

6. Sospolek--an acronym of sosial-politik-ekonomi much in use in official circles since the early 1960's.

7. The English phrase "floating mass" seems to have been coined in the aftermath of the 1971 general elections. It meant that the ordinary Indonesian villagers would be preserved by the authorities from political party propaganda and agitation.

8. Contemporary Djakarta slang for "arbitrary." 
of the Republic of Indonesia, Teuku Mr. Mohd. Hassan and Dr. Amir, returned to Medan, forthwith to carry out their new functions as Governor of Sumatra, and Minister of State without portfolio (permitted to reside in East Sumatra to work alongside the Governor). 9 Top priority: giving substance to independence.

Yet the Proclamation, which should have been broadcast far and wide at once, was kept folded up in the pockets of these notables (or at best was not publicized openly) for more than a month. Giving substance to independence amounted perhaps only to maintaining telegraphic contact between the Governor and Indonesian officials and notables in the regions and cities, which could easily be handled by the Posts, Telephone and Telegraph service.

It was only on September 30 , at a rather heated pemuda (militant youth) meeting at $\mathrm{Dj} 1$. Ampelas, Medan, that Governor Hassan (under duress?) declared that as a matter of fact Indonesia was already independent. Dr. Amir was not present. How meager and limited the activity of these high officials was can be seen from the fact that the Governor maintained his office in his own home. The office later used for this purpose was the former Balai Permohonan Rakjat [Hall of People's Appeals] in the Japanese time, now turned over thanks to the good graces of Mangaradja Soangkupon, 10 the Balai's chjef, the only official of that period who did not have a Japanese at his side.

From these developments it can be seen that the Japanese punctiliously obeyed British orders not to give any help whatever to the Indonesians.

During the month and a half of what was termed a "vacuum," Nicall agents, as part of the Allied military forces, carried on their activities in various parts of Indonesia, including East Sumatra and Atjeh.

9. The Panitia Persiapan Kemerdekaan Indonesia was established on August 7,1945 by the Japanese as the final stage in preparing for (nominal) Indonesian independence. The twenty-one-member body contained three representatives for Sumatra, the two men listed above and Mr. Abdul Abbas. Mr. Teuku Muhammad Hassan was born in Sigli in 1906, to an uleëbalang family. He received a law degree from Leiden University in 1933, and then entered the civil service. During the war he was a senior adviser to the Japanese Resident of East Sumatra with offices in Medan. Dr. Mohammed Amir was born in Talawi, West Sumatra in 1900. He obtained a medical degree in Holland in 1928. In 1937 he became personal physician to the Sultan of Langkat. During the Occupation, he was a member both of the East Sumatra Residency Advisory Council, and of the Al1-Sumatra Advisory Council. He died in 1949.

10. Abdul Firman gelar Mangaradja Soangkupon was born in 1885, to an upper-class family in Sipirok, Tapanuli. He was among the best-known Batak leaders of his generation. He had a long civil service career in East Sumatra and Tapanuli, and was elected to the Volksraad in 1927 as a member for East Sumatra and Riau. In 1931 he was elected to the Volksraad's "executive committee," the College van Gedelegeerden. In the Volksraad he was for ten years a member of Thamrin's National Fraction; in 1938 he was made chairman of the "Indonesian Nationalist Group" in that body. During the Occupation he was a senior adviser to the Japanese Resident in Medan, and headed the body referred to in the text. He died on February 16, 1946.

11. Nica--Netherlands Indies Civil Administration. 
Because of the changed situation (above a11, the eruption of the Proclamation), these Nica agents openly undertook certain activities which were no longer limited to serving Allied interests, but were far more directed towards the Dutch colonial aim of destroying the newly established Republic--making every possible use of the opportunity known as the "vacuum" to arouse fear, anxiety, chaos and even conflict among the Indonesians themselves. Thus as soon as the Gunseibucho (Japanese Governor) announced in Medan on August 22, that the Japanese had surrendered, Dutch tacticians on missions "for" the Allies, under the cloak of the Red Cross or some other device, were swaggering around and getting very active. They set up headquarters in the Hotel de Boer and began to receive visitors. Their prime activity was: the issue of collaboration. They gathered information [on the collaborators], which could easily be obtained from (a) elements formerly loyal to the Dutch or glad to trade in gossip; (b) elements who "lost out" during the Japanese period; (c) those who hoped for positions and/or rewards under a Dutch "Restoration"; and (d) elements who were intimidated or blackmailed into giving information, adventurers, etc.

At the start there arose a feeling of uncertainty and insecurity. There were indeed elements in society, even leaders, who were genuinely against Dutch colonialism and had been active in addressing public meetings or raising political consciousness among the people during the Japanese period, who now, because they were afraid of being branded as Japanese collaborators, immediately dropped out of sight. On the other hand, there were elements expecting to make a comeback, who wandered all over the place at their ease because they had never been conspicuous during the Japanese period. There were also adventurers, criminals, recidivists and so forth who were fishing in troubled waters in their own characteristic way and by their own characteristic methods. All this, before the real mission of the Allies, the status of Nica and the people's right to determine their own destiny were clearly or widely known, seriously obstructed the creation of an atmosphere of calm and mutual understanding among the local populations.

At the beginning of October, British (Allied) troops landed in Sumatra and took up positions in Palembang, Padang and Medan. Troop shortages, however, severely limited the capacity of the British military to accomplish their mission. In Atjeh, for example, the British were compelled to assign a Dutch officer, Major M. J. Knottenbelt from the intelligence unit ADCS (Force 136), 12 with full authority as Allied military chief [pembesar] to enforce his will on the Japanese units stationed there in some strength--both to protect him as he proceeded to take actions he thought advantageous to his country's interests, and to arouse conflicts and antagonisms. He was there for quite a long time, from October 5 till November 10, on which day he was forced to take to his heels (it was no accident that this was the day the battle of Surabaja reached its climax). Dr. Piekaar's account in Atjèh en de oorlog met Japan, though a Dutch version of events, gives a picture of how Knottenbelt succeeded in worsening the atmosphere there by his intrigues. Masubuchi, a high Japanese civilian administrator, who was very wel1 known in Atjehnese circles, 'was compelled to take the desperate action of committing suicide (harakiri), although

12. ADCS--Anglo-Dutch Country Section--was a sub-unit of the we11-known intelligence outfit Force 136, operating out of Colombo under Mountbatten. For some details, see Anthony Reid, "The Birth of the Republic in Sumatra," Indonesia, No. 12 (October 1971), p. 32 . 
the unfortunate man had discovered much that had been concealed from him. ${ }^{13}$

On October 6, the Governor of Sumatra officially announced the formation of the TKR, an armed unit designed to fill out the authority of the government of the Republic. ${ }^{14}$ As in the capital, so in the provinces: the pemuda who did not join the TKR channeled their vigilance into bands which could more easily take to action and could operate more in accordance with the existing conditions and situation. This martial spirit, while basically an expression of a burning political consciousness, was evidently also a response to the hostile attitude taken by the Allied occupation forces themselves. Scarcely had he landed when the Allied Commander in Medan, [Brigadier-General] T. E. D. Kelly, ordered all inhabitants, without exception, to surrender their arms. This was a blatantly hostile "decree." Incidents sparked either directly by his troops (the fighting in Brastagi) or indirectly by his agents (the Djalan Bali incident in Medan), and by Nica (the Siantar Hotel affair), were a stern warning to the pemuda/ resistance fighters to increase their vigilance and preparedness. The Allies took over or seized building after building, both those used by the government of the Republic and those used by pemuda ormas, 15 particularly in cases where the Allies needed control over the building for strategic purposes or to weaken the growing capability of the Republican government.

While our pemuda/irregulars confined their preparations to defensive actions alone, the enemy fabricated a kind of anarchy. Armed robbery, torture and kidnapping of civilians, especially Chinese, suddenly broke out, though it had been unknown before. The aim: discrediting the purity and selflessness of the struggle. Investigation showed that the perpetrators were criminals evidently released from jail (by the British!) on purpose, among them a well-known "repeater," Amat Bojan. He was later encircled by our forces and shot in Brastagi.

13. S. Masubuchi was evidently a remarkable man. According to Piekaar (Atjeh, p. 191), he had been for many years a planter in East Sumatra and had acquired an outstanding knowledge of Indonesian society, and in particular of Atjeh. Piekaar credits him with being the brains behind the F (Fujiwara)-Organization, a "fifth column" organized mainly among young Atjehnese traders in the last days of Dutch rule. During the Occupation he held successively the following functions: chief of police and personal secretary to the Japanese Resident of Atjeh; head of the local information service and editor of the official newspaper Atjeh Shimbun; chief of the key "general affairs" section of the local administration; and finally, as war. conditions worsened, chief of the industry and communications section. Piekaar describes him as having "played the game of Atjehnese politics in masterly fashion" and adds that his popularity was so great that in certain Atjehnese circles he was referred to as bapak Atjeh (Father of Atjeh). According to Piekaar (Atjeh, p. 249), the Allied commander in Medan on October 21, 1945 ordered local Japanese military personnel to arrest Masubuchi (he was to be charged with war crimes), but the latter committed suicide to avoid this fate.

14. In Djakarta, on October 5, President Sukarno had proclaimed the formation of the Tentara Keamanan Rakjat (People's Security Army), to replace the more police-style Badan Keamanan Rakjat (People's Security Organization).

15. Ormas--organisasi massa (mass organizations)--an acronym coined and popularized only in the 1950's. 
Nonetheless, when this type of banditry had been successfully suppressed, T.E.D. Kelly had another card up his sleeve. He armed Chinese youths and formed a private army, the Poh An Tui, ${ }^{16}$ and played it off against us, a dirty tactic which can only spring from a dirty character. (As was later proved in court, the leaders of the Poh An Tui were robbers of the people's property and arsonists of the homes of ordinary Indonesian civilians, many of which were destroyed by their criminal activities.)

We may here record an incident which may have happened purely by chance, but which nonetheless should not escape attention. Several days after the Allies landed, the old Sultan of Deli died after a long illness. ${ }^{17}$ At this point neither the ruler nor his realm had expressed support for the Republic, in part because of their stand that Holland was the de jure owner of Indonesia, whose rights could not be overthrown just like that. By the terms of the "political contract" between the Dutch and Deli, the Dutch assumed responsibility for protecting the sultan in his status and authority. This provision represented a major element in the Sultan's interest, counterbalanced by the subtraction of almost all the Sultan's rights and powers as a sovereign, including the designation of a successor, who had to be agreed to by the Dutch. The presence of a high Dutch official was a conditio sine qua non for every inauguration of a new sultan.

So it happened on that disastrous day, when the new Sultan had to be announced--since "the king is dead, long live the king."ls In the official ceremonial hall where the court officials of Deli were gathered to call upon and anoint Tengku Mahkota Otteman (subsequently known as Sultan Osman Sani) as the new sultan, a high Dutch official was present. Also present was a British major, an event which could be interpreted as a move to strengthen the "legality" of the Dutch position in the Allied occupation phase. Automatically, such occurrences represented a stance denying the Republic's rights and sovereignty in Deli, or a demonstration of the Allies involving themselves in local affairs--something which they were forbidden to do.

Allied involvement in the affair of the Sultanate of Deli became even clearer when Allied commander T. E. D. Kelly subsequently protected the Sultan of Deli and the palace complex with a strong armed guard when the "social revolution" was at its height.

"Who's Who"

To get a rough picture of the atmosphere of the revolution in Deli, it may be useful to comment on the most prominent popular leaders of the period. Since the Japanese period, local leaders resident

16. Poh An Tui (Hokkien for Mandarin Pao An Tui)--Security Protection Force. In many places it was set up at Chinese initiative to protect the Chinese communities from robbery and violence.

17. This was Amaludin Sani Perkasa Alamsjah, who ascended the throne in 1924. The heir apparent, Tengku Othman (or Otteman), had been a member of the All-Sumatra Advisory Council during the Occupation.

18. Radja meninggal, radja mengebumikan--litera1ly, 'the king is dead, the (new) king buries him.' 
in Medan who were known to be active among the masses of the people, included:

1. Abdu'1 Xarim (read: Abdul Karim) Ms: ${ }^{19}$ an activist in the nationalist movement since the $1920^{\prime} \mathrm{s}$; 1ived in Langsa; involved in the PKI movement in 1926-1927; banished to Digul; brought back some years later; living in Medan with his relatives thereafter. Non-active in politics. Managed the small "Aneka" printing-press; published the popular weekly Penjebar. During the Japanese period, an old acquaintance of his called Hayasaki, who in the Dutch period had been a businessman, was assigned to Medan with the post of Mayor (Sichō). Hayasaki invited Karim to work with him, and made him head of the Information Institute (Balai Penerangan). Karim followed political activity in Java closely, taking special note of the way in which Sukarno and Hatta forged the masses via anti-Allied orpor. 20 He succeeded in inspiring the sympathy of the Sunseibucho (Japanese Governor) Nakashima, 21 and not long afterwards, by means of the support of the Bunkaka (Cu1tural Office = Information and Censorship Service), he formed the political organization known as BOMPA (Body for Supporting the Struggle of Asia). ${ }^{2}$ Taking advantage of this, he used every tour through the area to form branches and make contact with local leaders and notables. Although a Marxist-Leninist (and therefore naturally anti-Fascist), Karim did not make the slightest mention of the sources of his thinking in his public speeches, but rather stressed the vanguard role played by the Japanese people, who by their position at the waist of the continent of Asia corresponded to the position of the British at the waist of Europe. With this fact Karim associated the superiority of the Japanese, who seemed destined to assume the role of leader of Asia (our elder brother, on the same level with us, primus interpares), and capable of destroying Allied imperialism, under whose umbrella the Dutch took shelter.

of course, people with some basic political understanding had to laugh, half admiringly; for in such an atmosphere he could still

19. Abdul Karim M.S. was born in Langsa some time in the first decade of the century. He had virtually no secondary education. He was active in the Indische Partij, first in Lho' Seumawe (Atjeh) from 1918-20, and later as a member of the Al1Sumatra executive. While holding several low-level administrative jobs, he took an active role in the Communist-controlled Sarikat Rakjat and in 1924 headed the local PKI branch in Langsa (concurrently acting as the PKI Central Committee's commissioner for Sumatra). He was imprisoned on a number of occasions for his political activities. In 1927 he was exiled to Digul. He was released in 1928 and returned to Medan, where he worked occasionally as journalist and editor. In the Japanese period, he was briefly imprisoned in Tjimahi, but later was made an aide to the mayor of Medan, and became the head of BOMPA (see below). He was a member of the East Sumatra Advisory Council, and an observer attached to the A11-Sumatra Advisory Council. He died in Medan in November 1960.

20. Orpol (organisasi politik)--another acronym from the late 1950's.

21. Retired General Tetsuzō Nakashima was the Japanese Resident of East Sumatra. The Japanese title chōkan is variously translated as Resident and Governor.

22. BOMPA (given as an acronym for Badan Oentoek Membantoe Pertahanan Asia--Body for Assisting the Defense of Asia) was an East Sumatran equivalent of the Putera on Java, though it was set up in November 1944, just as the Putera was dying. For more details, see Reid, "The Birth," p. 24. 
stealthily achieve his aim of giving the masses some political awareness, although from another perspective the masses could not possibly comprehend how the Japanese, who were so curel and greedy, and were increasingly incapable of preserving the people from starvation and sufferings caused by every kind of deprivation, could possibly liberate our Indonesian motherland from Dutch imperialism.

Although he was a man well-known to the Japanese as a MarxistLeninist, Karim evidently aroused no suspicion, although his friends-including M. Ridjal--were beheaded for involvement in the underground. Karim once told me in passing how he succeeded in dispelling the suspicions of the PID (the Dutch secret police) while maintaining continuing contact with the Japanese Chamber of Commerce in Medan; and at the same time dispelled Japanese suspicions while maintaining contact with his old acquaintance, Bulat, chief detective of the Dutch secret police, who was deeply involved in smelling out the activities of any Japanese elements from the early 1930's on. This he did without compromising the national interest--and indeed, leaving aside the political philosophy he embraced, Karim was undoubtedly a real patriot.

Karim was an orator, an attractive speaker--like Sukarno he used language that was popular and easy for the masses to understand. He was strongly built, handsome, elegantly dressed with a necktie, and with personal manners rather unusual for a militant proletarian. If anyone mentioned this to him, he would respond quite spontaneously that the aim of the colonized was M(au) S(enang) [wants to have an easy 1 ife].

2. Saleh Umar, a nationalist leader, was in the Dutch period successively a leader of the PNI, Partindo and later Gerindo. ${ }_{3}$ As the son of an Islamic judge, born and raised in Brandan, he received a religious as well as a secular education. He was a writer (poet), and for a while published a small religious weekly, before becoming an active reporter for the Pelita Andalas, from there getting involved in the nationalist movement. A clever speaker, persuasive and skilled in politics-he was well up on theory, ideology, philosophy, etc., from studying on his own. In daily life he was not very outgoing; he was more at ease in his own small circle. During the Dutch period he was imprisoned. Had many children. For his own reasons he put two of his boys into Chinese schools from the primary level up--he never explained why he didn't send them to a national school--to the point that they graduated from a college in the CPR. Saleh's life-style was very modest, he had no talent for earning money even though his family was very large. Aside from his salary he minimally covered his expenses with honoraria for writings published by his admirers; possibly, too, his basic needs were eked out by the activities of his loyal wife Zahara. He was a close comrade in arms of Jakub Siregar (see below). His activities encompassed the world of the theater; by the products of his involvement with creative artists organized in the Kinsei Gekidan, the theater in East Sumatra, he can be said to have helped pioneer modernization. He was attached to the Bunkaka (Japanese Cultural Office); introduced as a nationalist politician, writer and poet, he became the No. 1 civil official in both politics and culture in that organization, about one year before the author joined this office (press and censorship division).

23. M. Saleh Umar was born in Pangkalan Brandan in 1909. He founded the Medan branch of Gerindo. 
3. Jakub Siregar was the son of a very we11-known nationalist businessman, Sutan Martua Radja, owner of the "Indonesia Printing Co.," who had once published the dailies Pantjaran Berita2 and Utusan Sumatra from about 1925 to 1935. Sutan Martua Radja had many sons who helped their father after they came of age. Not so, however, Jakub, who wanted to join the nationalist movement. Like Saleh Umar, Jakub Siregar was active in leading Partindo and later Gerindo, as well as working as a bush-lawyer. In this capacity he was often to be seen defending the poor. He was also very active as a leader, giving courses and attracting followers by educating them. On the eve of the Japanese invasion, he worked for their fifth column and became a leading "F," 24 thereafter cooperating actively with the Japanese. Later it was rumored that he was charged with masterminding an anti-Japanese resistance movement among Karo peasants, and he was arrested; but he was later released. After getting closely acquainted with the head of the Kempeitai [Japanese military police], Captain Inouye, a member of the Black Dragon Society specially assigned to the Sumatra front, Jakub cooperated closely with him, especially in training cadres among the fishermen and peasants, who might appropriately be made into a front line force to stem enemy infiltration. ${ }^{25}$ One organization that they formed and led in 1944 was called Ken Ko Ku Tui Sin Tai or, in Indonesian, Barisan Harimau Liar (Wild Tiger Corps). ${ }^{26}$

Jakub was rarely seen in public and did not mingle with other leaders during the Japanese period, but all of them knew about him. His wife, a beautiful woman with a MULO education, called Chadidjah, was also a capable leader, successfully training female cadres among the common people.

4. The figure of Hamka is sufficiently well-known. ${ }^{27}$ During the Japanese period, he was close to the Gunseibuchō, Gen. Nakashima, and

24. "F" refers to the "fifth column" organized out of Malacca, the full title of which was Fujiwara-kikan, after its creator Major Iwaichi Fujiwara. About one hundred young Indonesians (mainly Atjehnese) were trained between the fall of Penang on December 19,1941 and the Japanese landings on Sumatra. See Piekaar, Atjeh, pp. 77, 175-177; also George S. Kanahele, "The Japanese Occupation of Indonesia: Prelude to Independence" (Ph.D. thesis, Cornell University, 1967), p. $256, \mathrm{n} .45$. The trainees apparently wore armbands with the letter "F" for identification. Fujiwara soon turned over control to Masubuchi and went on to train cadres for Subhas Chandra Bose's Indian Independence Army. An account of his experiences is given in his Dai Tōa Sensō ni Okeru Atjeh Minzoku Undō no Kaikoroku [An Account of the Atjeh Nationalist Movement in the Greater East Asia War] (Tokyo: [?], 1955).

25. Capt. Inouye seems in fact to have been head of the Keimubu (civil police department) of the military administration in Medan. "Black Dragon Society" was the name popularly given in the West to the Amur River Association (Kokuryu Kai) founded in 1901 by the well-known expansionist and ultra-nationalist Ryōhei Uchida. See Masao Maruyama, Thought and Behaviour in Modern Japanese Politics (London: Oxford University Press, 1963), pp. 291-92.

26. Evidently a misprint for Kenkoku Teisintai (approximately, National Guard). The origin of the Indonesian name is unclear.

27. Hadji Abdul Malik Karim Amrullah ('Hamka') was born in Manindjau, West Sumatra in 1908, son of the famous reformist ulama Abdul Karim Amrullah ('Hadji Rasul'). He made a big reputation in the Dutch period as a modernist Islamic publicist, 
often gave speeches in mass meetings on commemoration dates. In supporting Japanese political strategy, Hamka was evidently shrewd enough not to make any reference to the verses of the Koran or the Hadith or the attitude of Islam towards Japan's war aims and its consequences in terms of the suffering of the Indonesian people. Nonetheless, on occasion his cleverness in this regard was excessively acrobatic, for example when he spoke of the Prophet breaking his fast with only three dates. In spite of the fact that Hamka's popularity could not decline, even though he had worked actively with the Japanese, and his position in society was pretty strong, about a month after the Proclamation Hamka decided to move to Minangkabau. (A memoir he once wrote in the daily Waspada--Hamka is till now a good friend of the writer--who continues to admire him--described his experiences at the start of the revolution, including, as he told it, having his house stoned.)

5. The journalist Adinegoro was formerly editor of Pewarta Deli. ${ }^{28}$ When this daily was closed during the Japanese period, he was assigned to handle the Indonesian edition of Sumatra Shimbun (later Kita Sumatora Shimbun), whose size was limited to a handkerchief-sized page. Actually Adinegoro was a leader very little known in personal terms by society, but, on the other hand, was widely known from his writings. Aside from describing and analyzing current problems at home and abroad, he also offered much political guidance via the newspaper that he edited. Through the press he was able to form many cadres whom he did not know personally, but who gained their political consciousness thereby and implemented the patriotic struggle from the products of his newspaper advice.

During the Japanese period, he often wrote editorials in his paper, which, though they oratorically praised the Japanese and strongly condemned the Allies, yet subtly but clearly conveyed another message between the lines to his readers. As an official in the censorship division of the Japanese Office of Culture, the writer felt this as others did, but for obvious reasons did not black them out.

When towards the end of 1944, a Sumatran parliament (Chūō Sangi-in) was formed, Adinegoro moved to Bukittinggi because he was appointed general secretary to that body. ${ }^{29}$ He was replaced by Jahja Jakub, a HBS graduate, who was for a time a teacher in a Muhammadijah school,

newspaper editor, and author. He was also a prominent member of Muhammadijah. During the Japanese Occupation, he was a member of both the East Sumatra Residency Advisory Council and the All-Sumatra Advisory Council.

28. Djamaludin Adinegoro was born in Sawahlunto, West Sumatra, in 1904, to an upperclass Minangkabau family. He had a good Dutch education and studied in Europe. On his return he made a successful career as a writer, journalist and newspaper editor. In the Japanese period, he sat on the East Sumatra Residency Advisory Council and on the All-Sumatra Advisory Council; he was also secretary of the Sumatran equivalent of the Badan Penjelidik (Investigatory Body), established in July 1945, which made studies of preparations for independence. He was a half-brother of the well-known nationalist politician and author Mr. Muhammad Yamin.

29. The author uses the anachronistic DPR (Dewan Perwakilan Rakjat--People's Representative Assembly [parliament]) to describe the All-Sumatra Advisory Council (which actually only met once, on June 27, 1945). 
but after becoming an intimate of Karim Ms, was taken in by Marxism. ${ }^{30}$ As a journalist, his analyses were close to those of Adinegoro; yet during the transition from the Japanese to the Republican periods, his newspaper, Kita Sumatora Shimbun, for a long time stayed stuck in its Japanese outlook, as indicated by the fact that it took a long while before the news of the Proclamation of Independence was printed in its pages.

6. Sugondo Kartoprodjo, a Taman Siswa leader, was well-known locally because his Taman Siswa school was part of the school system built up and enriched by the nationalist and patriot, Ki Hadjar Dewantoro, as a nationalist fortress against colonialism. ${ }^{31}$ Sugondo had many former pupils who had gone back or down into society, so natural$1 y$ it was easy for him to gain a position as a popular leader. This has already been demonstrated in the Dutch era when he had once been successfully elected to the [Medan] Municipal Council. He was often to be seen taking part in popular meetings and rallies. But during the Japanese period he was assigned to be chief of the bureau of social welfare, and there suffered a decline in prestige because the Japanese, using the term "superfluous/useless men" (i.e., the unemployed), demanded the mobilization of such people for "voluntary" defense work (kinrōhoshi) in Sabang, using his office as the channel for their propaganda. Nevertheless, Sugondo was not a failure as a leader, but rather, since he was not a taker of initiatives, he was felt to be a nationalist in speech rather than in giving actual leadership.

Beyond these men, one could hardly say there were national-caliber leaders who could be called real leaders of the people; but of course there were plenty of regional-caliber leaders.

With respect to leaders from the intelligentsia/elite, their prominence depended on their functional positions in the government: a good example was Teuku Mr. Hasan himself, who was appointed Governor of Sumatra by the Central Government of the Republic. Although he frequently appeared at meetings of Islamic organizations in the colonial period, he never put himself on the front line, and at best could be classified as a "salon-leader." He had a law degree (in Islamology), and became a referendaris in the office of the Governor in the Dutch period, the highest rank that could be attained by a "native" in those days. In the Japanese period he was made a senior advisory official, again the highest position open to an Indonesian at that time.

The most interesting thing about him was his conduct at work and in his private life. He was very simple and modest, not at al1 arrogant though he was the son of a radja (Teuku Bintara Pineung Brahim); he was basically non-political, but a faithful believer. Perhaps that was why he caught the government's attention, though as Governor he should have been flexible, and ready to take decisive initiatives.

As for Dr. Anir, a brilliant psychiatrist without rival in his generation, his wife was a beautiful Dutchwoman, with two children.

30. Jahja Jakub was born in Labuhan Bilik, East Sumatra, in 1915. He was a we11known journalist in Medan before and during the war. He spent nine months in Sukamiskin prison in 1941 for violations of the colonial press laws. HBS--the elite Dutch-language high school of the later colonial period.

31. On the Taman Siswa schools, see Ruth T. McVey, "Taman Siswa and the Indonesian National Awakening," Indonesia, No. 4 (October 1967), pp. 128-149. 
When Amir worked as court doctor in Tandjungpura, it was evident that she was his inseparable companion and adviser. Amir was a nationalist, but one whose activity was evident only in the articles he wrote for magazines and newspapers. These writings not only analyzed the decadence of colonialism but also urged a broad definition of nationalism, i.e., he opposed Java-centrism. Nonetheless Amir was only a success in his profession; he was a failure in the community, especially after he was made Minister of State without portfolio--an office he would not accept if it meant residing in Djakarta and abandoning the home in Tandjungpura that his wife loved so well.

Other leaders from the elite, such as Mr. Mohd. Jusuf and $\mathrm{Mr}$. Luat Siregar, both found their academic skills employed by the Japanese mayor of Medan, as Nos. 2 and 3.32 Jusuf had been a trial lawyer since the 1930's. Although he did not get deeply involved in the nationalist movement 1 ike the leaders he succeeded ( $\mathrm{Mr}$. Iwa Kusuma Sumantri and $\mathrm{Mr}$. Sunarjo), as a nationalist who never refused to take up the case of the poor and weak, Jusuf's position in the Indonesian community was much respected. As a political leader, however, nothing could be expected from him. Rather different from Mr. Luat Siregar, who was not very successful at his profession (most cases were monopolized by Dutch lawyers) but was able to follow and adapt to patterns of social intercourse in the middle class and below. In the Dutch period he was a Parindrist, but was not very active, even though he belonged to the moderate group. Later on, after becoming acquainted with Abdul Karim Ms, he gained prominence as a Marxist leader at Karim's side, as was a1so the case with another Parindrist, S. M. Tarigan, who after working alongside Karim, became a Marxist and a Karimist (possibly best encapsulated by the term Marxist-Karimist).

Other leaders came from the religious groups, such as $H$. Abdul Rahman Sjihab, Udin Sjamsudin, Junan Nasution, etc., and such Christian leaders as M. Hutasoit and Melanchthon Siregar. ${ }^{3}$

Of course many other names should be recorded as playing leadership roles in East Sumatra at that time. My intention is mentioning the above names is to point up the immediate post-Proclamation period. For had they or even one of them immediately stepped forward as the

32. Mr. Mohammed Jusuf was born in Magelang, Java, and obtained a law degree from Leiden University. He then went on to practice law in Medan. Mr. Luat Siregar was born in Sipirok, Tapanuli, in 1908. He obtained a law degree from Leiden in 1934, and then went into practice in Medan. In the Japanese period he was a secretary to the Japanese mayor of Medan, and was active in BOMPA. (He died in 1953.)

33. H. Abdul Rahman Sjihab, a Mandailing Batak, was a prominent Muhammadijah and later Masjumi leader in East Sumatra. Udin Sjamsudin, born in Medan in 1907, was active in the modernist Islamic movement. From 1932 to the middle 1950's he was secretary-general of the reformist social-educational association Al Djamiatul Washlijah. Junan Nasution, born in Kotanopan, S. Tapanuli, in 1914, had an Islamic education and was thereafter active in reformist Islamic politics, mainly as a journalist and editor. During the occupation, he was head of the Muhammadijah in Medan. Marnicus Hutasoit was born in Siborongborong, N. Tapanuli, in 1910. Prior to the war he was mainly active as a schoolteacher; during the Occupation he had an administrative position with the Medan authorities. Melanchthon Siregar was born in Pesarung Negeri Paranginan, N. Tapanuli, in 1913. He too worked mainly as a schoolteacher until the end of the war. 
extension of the people's tongue, ${ }^{34}$ openly or spontaneously transmitting the news of independence and at the same time urging its realization, the delay in the communication of this vital news would not have caused such great confusion in the people's minds.

But there was one other leader who cropped up quite unexpectedly after the news of the Proclamation and the Allied landing got round. This was Junus Nasution, a former clerk in the British Fraser \& Neave lemon-squash factory in Medan. ${ }^{35}$ I have no idea by what channel he became so prominent so suddenly. I had known him for a long time, from the colonial period, but just enough to nod politely to if we met; if we talked, it was just trivia. As a Mandailinger, his circle of acquaintances was probably confined largely to that group; yet it seems unlikely that it was from them that he climbed the ladder to take so prominent a part in the struggle to give content to the revolution. I never heard that he had ever belonged to any political organization. Nonetheless, recalling that he was formerly a bosom friend of M. Djoni, the Fat Bison of Deli, who later became the general chairman of the Red PKI in Jogjakarta on the eve of the transfer of sovereignty, at the very least he must have been a man who followed political developments closely. ${ }^{36}$

Before I went to Java in February 1946, his position was already very high--Assistant Resident, deploying directly the authority of Resident Tengku Hafas, pangrèhpradja [high civil servant] and aristocrat from the Sultanate of Deli, who had been named Resident of the Republican Government by Governor Hassan. The writer was astounded when he returned several months 1 ater and went to inspect the prison camp at Raja, to find Junus Nasution held there along with other prisoners of the aristocratic group. So quickly did he rise, so quickly did he fall.

Notes and Data

As has already been mentioned, the two leaders $\mathrm{Mr}$. Hassan and $\mathrm{Dr}$. Amir returned from Djakarta towards the end of August, 1945. From subsequent inquiries, the writer learned that the two of them came to

34. The author here uses Sukarno's self-bestowed title penjambung lidah rakjat.

35. M. Junus Nasution seems to have known Tan Malaka when the latter was teaching in the Medan area after World War I, and to have come under his influence.

36. M. Djoni was born in Kampung Gunung Manaan, Penjabungan, S. Tapanuli, in 1900. As a child he was taken to Mecca, and went to school there. On his return he had some minimal secondary secular education in Medan. While working with a Dutch private company in Atjeh, he became involved with the PKI and was barred from Atjeh as a result. From them on he was in and out of prison, in part for political reasons. In 1939 he was jailed for the last time by the Dutch and was subsequently deported to Digul. In 1943 he was moved to Merauke. He seems to have returned to Indonesia (Djakarta) in 1947. He became a colorful and evidently rather notorious figure in Jogjakarta during the later revolutionary period, and was imprisoned at least twice as a troublemaker (it was probably then that he acquired the soubriquet Banteng Gemuk [Fat Bison]). Though he seems to have known both Tan Malaka and Amir Sjarifuddin, he was very much a "single-fighter" and led his own 'red' PKI as a private army. 
the fore because they were the choice of Sukarno and Hatta themselves, not of the Japanese. The change, which would restore Sumatra as an integral part of Indonesian territory (i.e., not according to the division of Japanese military responsibility whereby Sumatra was part of the main base area of Singapore and was under the Gunseikanbu in Bukittinggi) and furthermore would make Medan its capital (in fact consistent with the Dutch authorities' own [pre-war] plans for administrative reform) reflected the thinking that Medan leaders were needed to whom active top leadership could be entrusted. Medan had a variety of popular or community leaders, as sketched out above, but their administrative skills were a matter of doubt, though they were admittedly more creative and full of initiative. There was no popular leader like Dr. A. K. Gani in Palembang who was a university graduate, or even like $\mathrm{Sjafei}$ in Minangkabau or even Teuku Nja' Arif, who had a [Dutch] high school education. ${ }^{37}$ Most of them, like Karim Ms., Saleh Umar or Jakub Siregar, were champion orators. While $\mathrm{Mr}$. Mohd. Jusuf was known to be close to the people, he was an immigrant from Java, and thus did not have the key qualification of being a native son like Mr. Hassan or Dr. Amir. While Luat Siregar had a law degree, possibly his name wasn't yet well known in Djakarta. Furthermore, he was way behind such men as Karim Ms., Saleh Umar and Jakub Siregar as a popular leader. Thus it is not surprising that Djakarta's choice fell on Teuku Mr. Hassan and Dr. Amir. Nonetheless, as was subsequently demonstrated, the consequence of their timidity was that the needed rapidity in giving content to the Proclamation was never achieved.

There is some evidence suggesting that Mr. Hassan was appointed Governor at the suggestion of Dr. Amir, the leader whom Hatta possibly had in mind at the start. Amir preferred to be Minister of State and proposed Hassan in his place, with results we shall see later on, since he sat at Hassan's right hand and controlled the snelheid [speed of action] of the Governor.

There are also indications that Amir was not really serious about the Proclamation, since he believed that the Dutch would not simply give up and that the Allies would not be willing to help us. Accordingly, he felt ambivalent, and "telepathized" his "psychoanalysis" to Hassan. Always at Hassan's elbow, he was able to influence him considerably, doubtless thanks to his "scientific analyses."

It so happened that just after the two leaders returned from Djakarta, the writer was invited for the weekend to Dr. Amir's home in Tandjungpura, along with Karim Ms, and Jahja Jakub. We were told that Mr. Hassan and Dr. Amir would give us their analysis of what they had brought back, and would then formulate, or at the very least adumbrate, the "follow-up" they planned. But in fact all we did the whole night long was chat and gossip about trivia, the more easily since all of us

37. Dr. Adnan Kapau Gani was born near Bukittinggi, West Sumatra in 1905. He was graduated from the Djakarta Medical College in 1940. Aside from a career in films and the theater, he was a prominent young nationalist. He was a member of Partindo, and co-founder and first chairman of Gerindo. He was imprisoned by the Japanese in Palembang. He was later released, and even made a member of the local Residency Advisory Council and the All-Sumatra Advisory Council. Mohammed Sjafe' $i$ was born in 1895 or 1896 . He became famous primarily for founding a pioneering experimental nationalist school at Kajutanam, West Sumatra. During the Occupation, he was chairman of the West Sumatra Residency Advisory Council and the All-Sumatra Advisory Council. 
were good joke-tellers and raconteurs. But they were silent whenever the slightest serious question was raised about their impressions from Djakarta and the "follow-up" they had in mind. This in spite of the fact that they would have lost nothing if they had revealed to the writer that the Proclamation had been sparked and the text read, and the writer had then broadcast it widely. Wouldn't it actually then have spread rapidly throughout the community?

As a shrewd and quick-thinking man--as the saying goes, the mirror is quick to the face, the axe is quick to the foot--Karim Ms. had begun to cultivate these two leaders from the moment they stepped into the limelight in the last month of the Japanese Occupation, especially Teuku Hassan, who was more easily approached, since both were immigrants from Atjeh. There is convincing evidence that Karim had already learned about the fact and the text of the Proclamation privately from Teuku Hassan. If this is so, then Karim's silence and failure to broadcast the news of the Proclamation on his own must be regarded as a failure of responsibility as a leader of the people. This indeed was Karim's weakness. At that point the writer decided to take steps on his own, to find a financier willing to publish a daily newspaper, in which the writer would assume full responsibility, particularly vis-à-vis the authorities--for the newspaper would be published independently, without 1 icense from the government. But because of the many problems involved, it was only on September 29 that this paper, the Pewarta De $i$, could appear for the first time.

In the meantime, the popular leaders mentioned above were active/ inactive more or less as follows. While Karim himself seemed still to sit with his hands in his lap, his son Nip Karim, a pemuda who shared none of his father's taste for speeches, formed an armed unit, and, as later became well known, played an important role in the Medan area, with his headquarters in the Two Rivers plantation near Deli Tua. Possibly all that he got was his father's blessing, but the son's forces were strengthened with the addition of deserting Japanese and KNIL officers, and looked convincing enough to rely upon. ${ }^{3}{ }^{8}$

It was very clear that, in a period when news of the Proclamation was still obscure, there was a great need for prominent leaders to provide information and guidance, at the very least to prevent panic, misunderstanding and deliberate distortion for the purpose of creating confusion and error. In Djakarta the newspaper Asia Raya courageously continued publication and was successful in using its pages to spread the news of independence. In Medan, on the other hand, the Kita Sumatora Shimbun, under Jahja Jakub's leadership, published no reports of independence, and continued to take its proof copy to the censor for checking, even though the writer himself, who, as a member of the censorship staff had long been accustomed to the daily passing and stamping of copy coming in, had quit on August 22, the day that the Japanese Governor announced the Japanese surrender. Since the Kita Sumatora shimbun continued to hand in proof-copy, the man who replaced the writer, Azis Latif, without having authority transferred to him, continued with the censorship until the end of september, even though al1 the Dōmei news by then was completely empty. ${ }^{39}$

38. KNIL--Konink1ijk Nederlandsch Indisch Leger (Royal Netherlands Indies Army)-was the Dutch colonial army.

39. Dōmei was the Japanese wartime news-agency. 
As for Saleh Umar and Jakub Siregar, the word was that the moment they heard the explicit announcement that the Japanese had surrendered, they hurriedly left for the south. They were lucky enough to run into Dr. Gani in Palembang, and from him they got a clear picture of the Proclamation and the need to give it content. Saleh Umar returned at once to Medan to carry on work among the people. But Jakub Siregar, together with his wife and Mansur, a loyal "aide," continued his travels and crossed over to Java. For some months he took a holiday in West Java (this was what Mansur told me when I met him in the Hotel Merdeka in Jogjakarta, describing his disillusionment).

So it was that at that time, and especially in Medan, there was an unsettled atmosphere which permitted the growth of all kinds of confusion. For example, towards the end of August 1945, there was a broadsheet circulated, signed by members of the functional elite (including the radja) urging the people to stay calm and orderly. It was clear enough that this broadsheet was meant quite sincerely and innocently but in fact it aroused great suspicion because its signers were for the most part from aristocratic circles, whose attitude towards the Proclamation was rather dubious. It is true that among the signatures there were two or three popular leaders, but precisely that created the impression that they were being used as a shield. It is a pity that the writer did not save a copy of this broadsheet for archival purposes. It would be a good starting point for a study of the development of the "social revolution" in East Sumatra with all its good and bad effects.

The atmosphere continued to change, and finally, since there was no word of initiatives on the part of the older leaders (functional and non-functiona1), the pemuda names came increasingly to be heard on people's Iips. Among them was Sarwono Sastrosutardjo, a former teacher in the Taman Siswa school-system. It was he who later became the leader of Pesindo in East Sumatra. ${ }^{40}$ Although he was considered a pemuda, actually he was already married. A friend of his, Zainal Baharuddin. was also active as the organization's general secretary. ${ }^{4}$ Later developments showed that Sarwono frequently met with Karim Ms., and became a Karimist. One gets this impression from the fact that Karim succeeded in having Sarwono made a member of the National Parliament as a member of the Sumatra PKI's quota. ${ }^{42}$

After Governor Hassan's announcement in Djl. Ampelas, the revolutionary atmosphere became rather more clear, especially after the landing of the Allied troops. Karim Ms. was no longer silent and passive. He paid continual attention to the writer when the latter was actively directing the independent newspaper Pewarta Deli (which was published without official permit) after september 29. One day he came to show

40. Pesindo--Pemuda Sosialis Indonesia (Socialist Youth of Indonesia). It had no organizational or even clear ideological ties with the Pesindo which developed in Java at about the same time.

41. Zainal Baharuddin was born in Kutaradja in 1908. He trained as a schoolteacher and in the last years of Dutch rule taught in a Muhammadijah school in Kuala Simpang. At the end of the Occupation he was teaching in a high school in Medan.

42. Sunatra was a1lotted a quota of seats in the Central National Indonesian Committee (KNIP), the national parliament of the period. Evidently the local PKI was assigned a segment of this quota. 
a telegram from Sukarno ordering him to form and lead a single party, the PNI, for all Sumatra. But several days later he annulled this possibility himself; for Saleh Umar, who had just returned from Palembang, had evidently been given a mandate for this purpose by Dr. A. Gani, whom Sukarno had assigned to build up this party in Sumatra. Not long afterwards, Karim came to see me and told me that he was going to set up a PKI in Medan, and had already sent a cable to Mr. Moh. Jusuph, the founder of the first PKI after independence was proclaimed, which had its headquarters in Tjirebon. ${ }^{43}$ The writer made no response to this, and Karim himself made no overtures; he knew that the writer was not a man who could be attracted to Communism or turned into a Communist, since by temperament, style of thinking and character, as well as by ideals, he was not a man prone to jump hither and thither in the dark.

It appeared that Karim himself was no longer passive and silent, but made strenuous efforts to be constantly at the Governor's side. His official function was still unknown when he was able to gain much influence from this close association, but later he was able to get appointed as Resident seconded to the Governor's office. In the meantime, the question of who was friend and who was foe (enemy, collaborator, etc.) was becoming very important, since arms were falling into the hands of different groups. When the Japanese began to feel sure that the British would not be able to move outside the capital city (indicated by the fact that the British were willing to request the help of the Republic in releasing prisoners of war and disarming the Japanese, and indeed ordered the Japanese military to hand over supervision of the BPM oil-wells at Pangkalan Brandan to the Republic), they understood that the question of providing an inventarization of the weapons and vital stocks in their possession, which the British required, would be no more than a formality.

But in fact the Japanese knew very little about the growth of the Republic, its administrative apparatus and the official holders of authority. Indeed on one occasion their obedience to British orders was so abolute and cruel (sadis) that they caused the December 13 massacre in Tebing Tinggi, simply to demonstrate to the British that they were not in collusion with the Indonesians, in so far as weapons passed into the hands of our pemuda and irregulars. On the other hand their stupidity was so great that they believed that those who were entitled to receive the weapons they handed over (b) either ruse or bribe) were only those who had mingled with and cooperated with them. Most of them had no idea who were the real patriots and freedom-fighters, so that only too many weapons fell into the wrong hands (adventurers), or into the hands of sultans, radja, .or uleëbalang, whose political consciousness and sincerity of intention were scarcely convincing. This occurred, for example, in Asahan, where the local Japanese officer transferred some weapons to the Sultan, whom some people say the Japanese regarded as the functional Republican authority of the Republic.

As a result, each group or unit was increasingly anxious to obtain fighting strength (i.e., arms), as was evidenced by the way the

43. Mr. Muhammad Jusuph (Jusuf) was born in Indramaju, West Java, in 1910 . He received a law degree from the University of Utrecht in 1937. He was a leader of Gerindo in Bandung on the eve of the war, and seems to have been involved in some kind of underground activity during the Occupation. The post-war PKI was founded on October 21,1945 , though the news did not reach the metropolitan press till November 6 . 
Governor and his subordinates were kept busy meeting the irregulars' requests for materiel, not the least of which were all kinds of facilities in the economic sector. Unable to deny the new reality, the Japanese, who till now had controlled the rubber, tobacco and other plantations, abandoned them to Republican control. The workers ${ }^{4} 4$ in the plantations, industries, and other economic sectors were now able to do something to give content to the Proclamation. Some enterprises and plantations could be exploited directly--their products could be carried away, sold directly or exported overseas--and the profits used for purposes of defense. The British occupying forces seemed to take a laissez-faire laissez-passer attitude towards these export activities, and permitted the products of the former East Sumatra and Atjeh plantations to be taken off and sold on a large scale by our traders (who, killing two birds with one stone, were also freedom-fighters), since their destinations, whether Singapore itself, or Kelang and the ports of Malaya, were all still British colonies. This permissiveness had the effect of keeping basic prices low, while the British or their businessmen, whose profits had been small hitherto because of the absence of imported produce from Indonesia, need not run any risks; on the other hand, the price at which these goods were thrown on to the world market by Singapore ran up very quickly.

The British CID evidently made little serious effort to obstruct this barter trade (which allowed Indonesian patriots to smuggle in weapons from Singapore), since it helped the Singapore economy considerably. Clearly, though, considering how effective their administrative apparatus was, not one gun would have got through had they really been opposed--except where the smuggling was detected or blocked by the Dutch Navy itself.

The products of this barter trade were very significant for increasing the quantity of weapons required by our freedom-fighters in Atjeh and East Sumatra. Aside from that, the barter made it clear that our modern weapons were not solely the result of Japanese gifts. Indeed, as mentioned earlier, a good deal of the weapons from Japanese arsenals fell into the wrong hands. What Major Knottenbelt achieved during his stay in Atjeh (October 5 to November 10) is food for thought. Since August the British fleet had been stationed in Sabang and it included a Dutch warship. Had Knottenbelt really wished to prevent Japanese weapons from passing into Indonesian hands, it would have been easy for him to order all arms in Atjeh to be transported to the Allied warships in Sabang, leaving only a few ashore for security purposes. But Knottenbelt, protected by his function as Allied agent, carried on highly suspicious intrigues. Indeed it is very possible that his activities were the initial stimulus for the great suspicion the majority of the population felt with regard to a certain minority's sincerity in giving content to independence. He evidently expected that a struggle to the death between the two groups would weaken both, at which point he hoped he could emerge as a third party and reap the benefits. While he was in Kutaradja he exploited every opportunity offered him by the Republic's attitude that we were not in conflict with the Allies, indeed that we should extend our hands and be ready to provide assistance. The Resident did his best to help Knottenbelt, as evidenced by his willingness to make a dangerous sacrifice in arranging that when Knottenbelt had to leave for Medan in a hurry on

44. The author here uses the contemporary word karyawan (functionary) rather than the older buruh (worker). 
November 10 , he was not harmed on the way. After carrying out his duties and reporting to the Governor in Medan, perhaps $\mathrm{Nja}$ ' Arif already sensed the danger he was in, but his sense of obligation to be where duty called led him to return to Atjeh once again.

What happened in the following month led to $\mathrm{Nja}$ ' Arif's having to be "sent away to safety" in Takeungon. Former Major-General Husin alMudjahid ${ }^{45}$ subsequently told the writer that it was precisely because the People's Revolution group knew how innocent and honest Teuku Nja' Arif was, that they felt he had to be quickly taken away to Takeungon to prevent him falling victim to blind excesses. Mudjahid said that though Teuku $\mathrm{Nja}^{\prime}$ Arif was an aristocrat (aside from being Republican Resident of Atjeh, he was also Panglima Sagi XXVI Mukim), he was not against the revolution. That he died there in Takeungon was purely the result of God's power.

On December 12, the Japanese military headquarters in Lho' $\mathrm{Nga}$ (on the coast of Atjeh Besar) was attacked by the people. Many weapons were seized, though many of the attackers fell and about fifty Japanese soldiers were killed. This made an enormous difference to the fighting capacity of the resistance in Atjeh. Six days later, Allied emissaries in Ulehleh decamped.

Four days later, on December 22, violent armed conflict erupted between the freedom-fighters and the uleëbalang in Lam Meuloh (Pidië). Judging from the "press-release" of Teungku Abdul Wahab, First Chairman of the General People's HQ in Sigli, as communicated by the official Republican Government in Sumatra's newspaper Suluh Merdeka in Medan on January 9 , it is evident that large-scale clashes had broken out in Sigli, Lam Meulo and Meureudu. ${ }^{46}$ The press-release termed these clashes a "People's Revolution" opposing the activities of the counter-revolutionaries, masterminded by Teuku Mohd. Daud, the uleëbalang of Tjumbok. ${ }^{4}$ It was stated that by its announcement of January 6 , 1946, the Republican government in Kutaradja supported this revolution, which not long afterwards (January 18) was successfully completed.

News of the people's revolution in Atjeh spread down widely into East Sumatra, and was evidently not treated as smoke vanishing in the wind.

45. Teungku Husin al-Mudjahid was well-known in the late Dutch period as the militant leader of the Pemuda PUSA, youth arm of the strongly anti-Dutch ulama organization PUSA (Persatuan Ulama Seluruh Atjeh--All-Atjeh Union of U1ama). He was believed by the Dutch to be closely involved with the F-Organization. After the Proclamation of Independence, he became an important politico-military figure in Atjeh.

46. Teungku Abdul Wahab, ulama in Seulimeum, was a well-known PUSA leader in prewar days. He attained new prominence under the Japanese, as a member of the Atjeh Residency Advisory Council, member of the Japanese-instituted Residencylevel Islamic court, and head of the Seulimeum branch of the Maibkatra, the Atjehnese equivalent of BOMPA.

47. Teuku Sri Muda Pahlawan Bentara Tjumbok Muhammad Daud was among the most energetic and aggressive of the younger uleëbalang in the later Dutch period. (A sketch of his personality and early life is given in Piekaar, Atjeh, p. 129.) 
Whether it was connected or not with the influence of this news, on January 12,1946 , a statement was issued by various sultans in East Sumatra that they and their territories stood behind the Republic. This statement was conveyed in a meeting with the Vice-Governor Dr. M. Amir, accompanied by Resident Tengku Hafas and Vice-Resident Junus Nasution. But the only radja to appear in person was the Sultan of Langkat; the rest were represented by emissaries. These included Tengku Besar Radjih Anwar for Serdang (the Sultan himself did not appear because he was old and sickly). Deli was represented by two Datuk (there being no word as to whether the Sultan was prevented from coming by sickness). Asahan was totally not in evidence. (One could note here that these four kingdoms--Deli, Langkat, Serdang and Asahan-were the big principalities, the rest were quite small.) The presence of Dr. Amir representing the Governor gave the impression that the autonomous principality question belonged in his "file." Amir evidently saw that something was afoot. Or perhaps, in such an atmosphere, he was being seriously approached by the Sultan of Langkat both as to his thinking as well as on the matter of personal safety. Amir had worked since the Dutch period as Landschaparts (Doctor to the Principality) of Langkat, and the Sultan felt very well disposed towards him.

On February 3, a further official meeting was held with the rulers of East Sumatra, this time chaired in person by Governor Hassan. Attending for the Republican government were: Vice-Governor Dr. M. Amir, Resident Tengku Hafas, Resident seconded to the Governor Karim Ms., Inspector of Education Abu Bakar, Chief Prosecutor Muthalib Moro, A11-Sumatra Health Inspector Dr. Mansur, Vice-Resident Junus Nasution, and Mayor Mr. Mohd. Jusuf. For the Sultans there attended: Langkat, Siak, Deli, Asahan, Mahkota, Serdang, the Jang Dipertuan of KualuhLedong, the Sutan of Bila, the Sutan of Panei, the Radja of Siantar, Indrapura, Sukudua, Lima Puluh, Purba, V Kuta, and Raja and the Sibajak of Barus Djahe.

At this meeting, the Governor explained that the autonomous territories were recognized as special regions on the basis of section 2 of Article 18 of the 1945 Constitution. All expressed their support for the Republic, while the Governor stressed that they should go down into the community and act like fathers to the people.

If one took the outcome of this meeting at face value, one could conclude that the position of the autonomous territories and their officials was now cleared. But in reality things were much less promising. First of all, none of the sultans or radja involved were capable of becoming popular leaders or fathers of the people--they had never been educated or trained to fill such roles. This aside, their routine administrative functions, such as collecting taxes, directing corvée labor, and presiding over judicial proceedings, could no longer be carried on. Not only were people no longer willing to come to the rulers' offices because of the drastic change in the atmosphere, but often the rulers' officials themselves did not show up at their offices any more, having either adapted themselves to the developing revolution, or for other reasons.

The result was that only one choice still lay open to the sultans and radja: to listen to the radio in their palaces, quietly follow further developments, and, naturally, to find out what the attitude of the Dutch was and what the Dutch were currently doing to reconquer their colony. It was precisely this that unavoidably became a matter 
of vital concern to the sultans and radja involved. If they could sift out the news coming in over the radio, they could certainly conclude that the Dutch day was done. On the other hand, if they could not, they would be tempted by the possibility of a Dutch "come-back," this would have its influence on them, and the long-run consequences could be serious, especially if they continued to isolate themselves within their palaces.

In the event, things turned out precisely this way. The attention of the freedom-fighters was turned to the rulers. Reports from Atjeh revealed that part of the property of the overthrown counterrevolutionaries had been seized, and then collected together and entrusted to a commission specially established as a kind of probate office. The rulers' assets were paid out as compensation for people who had suffered wrongs at the hands of these counter-revolutionaries. The whole business was organized with full accountability, and everything had to be approved by the Examining Council, which was specially set up and given authority for this purpose, inter alia to determine whether the seized property could be returned to the owners or was needed for carrying on the revolution.

From a11 indications, the Atjeh Affair was a matter of constant discussion within the closed circle around the Governor. It was not only that the Governor was in mourning for his father (who rumor had it was among the victims of the Affair); but was it not possible that, if the "people's revolution" spread to East Sumatra, a fate more or less like what had overtaken $\mathrm{Nja}^{\prime}$ Arif as a side-effect of that revolution might happen to him?

At that time, in the first two weeks of February, the writer was still in Medan and had no idea he would be sent on a mission to Java. It should be noted that in January the writer sat on the leadership board of the Sumatra Information Bureau: the director was Dr. Amir, his deputy was Mr. Luat Siregar, Jahja Jakub was head of the press section, and the writer in charge of the political and research sections. The secretary was Jusuf Abdullah Puar. But although the writer had been granted this official designation, after inauguration he never once went to the office or took part in its affairs, primarily because he felt very uncomfortable as a government official, and preferred to be independent, on his own, and secondarily because he knew that Jahja and Puar were more than adequate to run such an office. Nonetheless, since there was a need for the necessary leadership to observe the development of the revolution in Java, the writer was assigned ex officio to travel across to Java along with Jahja Jakub.

Nonetheless, our departure was still up in the air, for Dr. Amir hoped to be able to "bum" a ride on an Allied plane as he had done when he went to Java together with Mr. Luat Siregar. This left our departure up in the air, till in the end we decided to go by land.

Stepping down from the Sukamulia office staircase after the ceremony of accepting the allegiance of the sultans and radja on February 3 , the writer accosted Karim Ms. and jokingly asked him what all this business of assembling the radja to convey their sentiments of loyalty was about: Was it still another imitation of our Elder Brothers' style? ${ }^{48}$ He answered (evidently rather seriously) that the consequences

48. The reference is to the Japanese, who liked to term themselves the "elder brothers" of the Indonesians. 
would become clear once the Governor had left. It was only from this remark that the writer learned that the Governor was going on an inspection tour far to the south and would be away for a long time. The writer did not respond, though at that time he did not suspect there was anything behind it. Only after studying the events of the "social revolution" some years later, did the writer attempt to solve the problem of whether or not there was a "background" to the Governor's departure. Clearly there were various possible answers depending on one's starting point.

First of all, as the highest government authority in Sumatra, Governor Hassan was undoubtedly required to make inspection tours, both for purposes of consolidation and indoctrination, a synchronization activated by Sukarno and Hatta. Along with the Governor went various senior officials as well as Abdul Karim Ms. himself, the master orator. His participation would certainly aid the achievement of this goal. This first possible interpretation could, of course, be officially announced.

The second possibility was that the Governor was deliberately pushed (by Karim or someone else who knew that there is "no smoke without a fire") to go on a distant trip, so that uncontrollable elements could do as they pleased in the absence of the top Sumatran leadership, Governor Hassan. For in spite of everything, at the start of the revolution Hassan was a symbol allowing all the guardians of the revolution to declare that the Indonesian Republic was strong under his leadership. Thus, if he was not on the spot, he would not have to accept responsibility.

The third possibility is that the aim was to prevent excesses--so that the Governor need not be Teuku-Nja'-Arif'ed: in other words, so that with the launching of the "social revolution," the Governor as an aristocrat would not become its victim. It was for this reason that he was willing to choose to make a tour of inspection. Naturally neither the second or the third possibility could ever be made public. The writer himself was unsuccessful in establishing for certain whether these possibilities were merely his own "wishful thinking" or not, since Karim died before the writer got the idea of including the "social revolution" in his memoirs.

Another question which must be answered, if one wishes to complete this commentary, is: what was the real object of the East Sumatran "social revolution"? Was it to put an end to the adventurism of the counter-revolutionaries who were known to be very active and busy building up their forces, or was it simply to seize control of their possessions and property?

The writer met Dr. Amir in his office at the beginning of February --after the Governor had left for the south. I don't know why he summoned me alone, not along with $J$ ahja Jakub, when he handed me my credentials and a short report to be transmitted to Prime Minister Sjahrir. In a joking way, Amir said: "Now then, Saudara Said! Now that Mangkubumi's gone (that was our nickname then for Governor Hassan), we're freer to make decisions and act. I've managed to get Saleh Umar out of Allied jail today, in exchange for one of our Allied prisoners. He had a very bad time, beaten with rotan rods by Turk Westerling."49

49. The subsequently notorious Lieutenant "Turk" Westerling had been parachuted into Medan in the middle of September 1945 to organize an anti-Republican police 
Amir added that Saleh Umar was needed to expedite the revolution.

In those days, when we met, Amir would still crack jokes, a carryover from what we used to do to relieve the constant psychological pressure caused by Japanese oppression. But this time his heavy breathing and drawn expression gave the impression that he was hiding something very grave and serious behind what he said, and pretending that "we're just playing roles here now." He seemed to recognize that what he was facing was a reality, indeed a very grave one. What he recognized was in sharpest contrast to what he had assumed thus far: he had been totally wrong in thinking that everything was just a play. This recognition was plainly visible in his face and in his thinking.

At our meeting that day (which was also our parting), there was not a whisper about the possibility of a "social revolution." What happened after the writer left for Java evidently developed with extraordinary speed. On February 14 the writer was still able to attend the formation of the East Sumatra People's Front (Volksfront) under the twin top leadership of Sarwono and Saleh Umar. As soon as the writer returned from Java, he immediately set out to get reliable information on the course of what was called the "social revolution." In general, the answers were everywhere the same. The feudalists were in the wrong. Period! For this reason, much time was needed to gather real and trustworthy facts. Only four months after leaving East Sumatra, much had changed. Junus was under detention and Dr. Amir had fled to the [Allied] camp.

From reading back over the issues of the Medan newspapers while I was gone, I found a number of interesting items including the following: Major Ferguson is here, "social revolution" happens to break out.

From the first release, issued by the Bureau of Information (under Dr. Amir's leadership), it could be ascertained that by February 27 a certain Major Ferguson, an Englishman from the Allied Forces, had arrived in Medan. It was also reported that Vice-Governor Amir and party were taking Ferguson on an inspection tour that day to Asahan, from there circling round through Simelungun (Siantar) and returning again to Medan on March 2. The purpose of the Vice-Governor's tour was stated as being to check up on popular support for the Republic. The names of those mentioned as being in his party were Vice-Resident Junus Nasution, Dr. Sunarjo, Mangatas Nasution, Police Chief Abas, Nurmatias, S. H. Simatupang (Posts, Telephone and Telegraph), Muchlis, Adjib, Nazir, Harun Lubis, J. M. Zein, M. K. Kasiman (ERRI), Sabirin Gani (Pesindo) and $S$. Soufron (PKI). ${ }^{50}$ The party was really rather large, but the most interest thing [about it] was that Ferguson joined it. Surely it is too much of a coincidence that it was precisely when he

force. In this he was quite successful, though his comrade-in-arms, Lieutenant Brondgeest, commented on his "occasional use of somewhat inhuman methods." Westerling had been attached to the ADCS mentioned above. For more details on the activities of Brondgeest and Westerling, see Reid; "The Birth," p. 32.

50. ERRI--Ekonomi Rakjat Republik Indonesia (People's Economy of the Republic of Indonesia)--was a short-lived body set up at the height of the "social revolution" in the spring of 1946 to control plantation products and basic commodities, ostensibly at least for socialist purposes, and to prevent such supplies falling into Allied hands. 
was in East Sumatra and was on a tour through the area that the "social revolution" broke out. In Asahan they were the Sultan's guests.

On March 3, Major Ferguson held a meeting with Vice-Resident Junus Nasution, accompanied by Mr. Jusuf (who usually acted as interpreter) and Police Chief Raden Suleiman. This meeting was described as "cordial" by the Information Bureau in a circular, but nothing was mentioned about what was discussed.

The writer heard directly (at first hand) from one of the main actors in the Simelungun sector, A. E. Saragih Ras, that the "social revolution" was planned to break out simultaneously at midnight, March 3-4, 1946. On March 4 rumors were spreading rapidly. On the morning of March 5, Vice-Governor Dr. Amir issued a proclamation mentioning the occurrence of the "social revolution." He was the first to use the term without quotation marks. Evidently he considered the "smashing" ${ }^{11}$ of the aristocracy a social revolution. Perhaps the idea came to him then because he was reminded of the "smashing" of Louis XVI and Marie Antoinette who went to the gallows [sic] because the French wanted to destroy the monarchy with its class society and replace it with a republic with its sama rata sama rasa (Ziberté, equalité [sic], fraternitê). 52 What one heard had happened at that time in East Sumatra was butchery and seizure of property, but the abolition of the autonomous territories was not at that time one of the movement's aims.

The proclamation, personally signed by Dr. Amir himself, consisted of eight articles. Article 5 stated that government in East Sumatra was consigned to the hands of Junus Nasution, with the rank of Resident. (This meant that Resident Tengku Hafas was dismissed.) In performing his functions Junus was to be assisted by the Working Committee of the local National Committee and by the Volksfront. This proclamation was countersigned (supported) by the chairman of the East Sumatra National Committee, Mr. Luat Siregar. ${ }^{53}$ It was by no means clear whether all autonomous territorial institutions were abolished by virtue of this proclamation, or indeed what the substance of it precisely was. Of more long-term importance was the question of the very legality of the proclamation itself, its legal base and its legal consequences.

The Information Bureau was very active putting out communiqués, though these were very general and said little in detail about what had happened and why. Communique No. 2 stated that on that date the government had assigned two key leaders, Junus Nasution and $\mathrm{Mr}$. Luat Siregar, to tour East Sumatra to control the situation and ensure

51. The writer uses the word ganjang (Javanese for 'bite,' 'chew up') which was introduced into the Indonesian political vocabulary by Sukarno at the beginning of Confrontation.

52. Sama rata sama rasa--1it., on the same level, feeling as one.

53. Soon after the Proclamation of Independence, the central government had ordered the setting up of local National Committees at each level of administration to give direction to the revolution. Their power and effectiveness varied greatly from area to area and level to level. In most cases, owing to their relatively large size and infrequent meetings, their powers were delegated to so-called Working Committees, which acted as "day-to-day executives." 
security. The next report stated that on that very day, March 5, Mr. Luat had left town, taking with him in his party Sarwono, Saleh Umar and Sutjipto. (There were apparently two Sutjipto's--one a son-in-law of Karim Ms., a colonel, left-wing like his father-in-1aw, who later left the army; the other reportediy becoming a major and being assigned to the economic sector.) It was reported that the area to be covered by Junus Nasution, who also left town, was to be Tanah Karo and Langkat. The reports on Junus' expedition out of town mentioned that he had already successfully brought order to Bindjei and Sunggal. From there he continued his tour to Brastagi, accompanied by a party from the National Committee.

On Asahan, it was reported that there had been some resistance and that the Sultan had finally fled after this resistance was broken. A clash had occurred at Pulau Buaja (on the Asahan River). It was reported that the Sultan later surrendered and that his troops were disarmed.

With regard to the announcement of the abolition of the autonomous territories, some were publicly proclaimed, others were handled more casually. One mass meeting held in the courtyard of the National Committee in Djalan Mahkamah on March 7 took the decision to abolish the autonomous territory of Deli. On that occasion Mr. Mahadi, exsecretary to the Sultan, was present.

The announcement of the abolition of the principality of Langkat was made at a mass meeting in Bindjei. Subsequently a party led by Sarwono, Jusuf Puar and Malik Munir visited Langkat on March 12 and held various meetings there. ${ }^{4}$ The Englishman, Major Ferguson, went along, accompanying the party as far as Teluk Aru.

Further, the announcement of a series of new appointments was made public to establish a new, direct system of government. Government in Simelungun was entrusted to Urbanus Pardede, assisted by Madja Purba; in Asahan to Abdullah Eteng, assisted by Sori Harahap; in Labuhan Batu to Abdul Rahman and Dr. Hidajat. It was also reported that the aged Jang Dipertuan of Kualuh-Ledong had been killed. In Batu Bara administration was put in the hands of Umar Pane.

But alongside all this activity by civilian leaders, an announcement was also issued by the TRI Division Commander. This announcement, signed by Col. A. Tahir at noon on March 5, declared that government throughout East Sumatra had been taken into the hands of the TRI. 55

54. Malik Munir was a leading figure in the nationalist scouting movement in Medan before the war, and also taught in Muhammadijah schools in various parts of Sumatra. During the war he was an advisor to BOMPA. Many of the more activist pemuda, such as Sarwono, Tahir and others had been scouts or students under him.

55. In January 1946, the name TKR was changed to TRI (Tentara Rakjat Indonesia-Indonesian People's Army). Achmad Tahir (real name, Hopman Sitompul), was born in Kisaran, N. Sumatra, in 1924. He joined the Giyügun (Volunteer Army) established on a highly decentralized basis in 1943 by the Japanese authorities in Sumatra. Unlike the Peta in Java, the Giyūgun was only organized up to the company level. Tahir was highly successful and ended up as a shōtaichō (company commander). After the Proclamation of Independence he was active, with Malik Munir and others, in setting up a Barisan Pemuda Indonesia (Indonesian Youth League) in Medan, one of the better disciplined irregular units. Shortly 
The announcement meant that governmental authority from that moment passed under military control. Whether this was done at Col. Tahir's personal initiative or was the result of a mandate he received from Dr. Amir, is by no means clear. What is quite certain is that the authority to declare this SOB (martial law) was not granted by the center--given the conditions existing then it was not possible that the critical news from East Sumatra had yet reached the center.

On March 14, Dr. Amir signed a decree on the formation of a collegial government for East Sumatra. He formed what was known as the Governing Council, composed as follows: Chairman, Junus Nasution; Vice-Chairman, Dr. Gindo Siregar; members, Hadji Abdul Rahman Sjihab, M. Saleh Umar, and A. Muthalib Moro. ${ }^{56}$ Here again Junus' name appeared conspicuously in first place--whether as a result of close cooperation between him and Amir, or because he had put Amir under heavy pressure.

That the situation was still far from clear can be seen from the appointments made on March 23 by Col. A. Tahir under his martial law authority. He appointed Mahruzar, a "businessman," as Resident of East Sumatra, and Moh. Jusuf as Mayor of Medan with a Governing Council for East Sumatra consisting of Dr. Gindo, Moro, Sjihab, Junus Nasution and Saleh Umar. In this 1 ist we can see that while Junus was still included, his position had declined; the same happened to Saleh Umar.

Thus in the space of less than two weeks we can observe the position of Resident passing from T. Hafas to Junus Nasution to Mahruzar.

Meanwhile, in the first week of April, Governor Hassan returned from his tour of inspection. His first act was to issue a proclamation on April 9 abolishing military government, and putting power back in civilian hands as normal. On April 12, he appointed Mr. Luat Siregar as Resident of East Sumatra, at the same time relieving Mahruzar of his post. Luat was succeeded as Chairman of the East Sumatra National Committee by $\mathrm{Dr}$. G. Sunarjo. On April 25, Dr. Amir fled to the Allied camp.

\section{Darkness in Light}

For a long time indeed after his return from Djakarta, the writer tried to obtain somewhat reliable data about the "social revolution," but without success. What one heard when the affair was still "hot" was all in the same vein and from the same perspective: the rulers and aristocrats were traitors to the revolution, agents of the Dutch or Fifth Column. That was why action had to be taken against them. More than that, one still frequently heard loud threats that anyone taking the side of the rulers would be regarded as traitors too and

thereafter he joined the new Republican Army. (For material on the Giyūgun, see Kanahele, "The Japanese Occupation," pp. 128-129; for some background on Tahir, see Mekar Sari, June 1, 1966; and Kelompok Kerdja Staf Angkatan Bersendjata, Sedjarah Singkat Perdjuangan Bersendjata Bangsa Indonesia [Djakarta: n.p., $1 \overline{964] .)}$

56. Dr. Gindo Siregar was a well-known plantation doctor and nationalist in the Medan area before the war. 
would be dealt with, just as their masters had been. As far as proofs went, all kinds were on sale; whether they were plausible or implausible was a secondary consideration. For example, there was a widelycirculated story that a Dutch flag had been spread out on the flat roof of the house of Tengku Musa, the second man in the sultanate of Asahan, and a man notorious for his Dutch ways. No one would be suicidal enough to express any open doubts on this.

On the other side, in the area occupied by the Allies and NICA, the talk was also in one vein and from one perspective--only the direction was 180 degrees away. The leaders and the pemuda of the Indonesian Republic were terrorists whose one aim was to butcher the feudal group and steal their property, precisely in order to take their place as a new feudal group. Republicans in the occupied areas, who were now there in the minority, had to suppress their feelings, particular1y after the Republican capital of Sumatra had to be moved from Medan to Pematang Siantar. Most of the photographs on the development of our Air Force under Commodore Suriadarma, which the writer brought from Jogja and which had just been put on display in the window of his office at Pusat Pasar 126 , were ruined and scattered by native NICA troops who evidently could not stand the sight of our capability in this sector.

Accordingly, all these contradictory reports must be sifted with a critical eye if one wants to obtain some reliable documentation of the period. For what could be noted down at the time about the "social revolution" were only vague and obscure reports which needed serious checking. On one occasion, when the writer had only just returned from Djakarta, and was in the interior (de facto Republican territory), he joined the party of a committee of the East Sumatra legislature on an inspection of what was called a "People's Prison." But neither from the party as a whole nor from the individuals in it did the writer get any useful information, except that the prisoners were very well treated, and that some of them had been put away simply to safeguard their physical security. When we arrived at the People's Prison in Raja, the writer met two aristocrats, Tengku J. (Serdang) and Tengku M.A. (Langkat). Since they were personal acquaintances of the writer, they had no hesitation in expressing their protests--among other things they asked why they were under detention and why they had not been brought before a court of law if they had indeed committed any crimes. Naturally the writer could only answer with a smile--at that time, he was only a reporter for Antara. (Note: When the writer met Adam Malik in Jogja c. April 1946, he was given a full mandate to build up branches of Antara throughout Sumatra, with the writer himself as chief resident representative. ${ }^{57}$ When the writer met Minister of Information Moh. Natsir in Djakartd and took the opportunity to pass on his impressions of his travels from Djakarta to our frontmost lines in Surabaja, he expressed his conclusion that the number one priority program for Sumatra was to disseminate fully all revolutionary activities via the medium of Antara, i.e., that the activities of the Ministry of Information were not enough in themselves. Natsir expressed his strong approval of this conclusion, and accepted the writer's request not to have to be appointed a high Information Ministry official.)

57. Antara (originally founded in 1937 by Adam Ma1ik and other nationalist journalists, merged with Domei by the Japanese, and re-opened after the Proclamation of Independence) was the semi-official Republican news-agency. 
In another "People's Prison"--for VIP's, in the house of the former administrator of the Bah Birung Ulu Estate, the writer met the Sultan of Asahan. ${ }^{58}$. He made no bones about showing his anger at the way that he had been treated. From the Sultan himself the writer learned that he had indeed received some arms, a few rifles, from the Japanese. The Japanese intent had been to turn these weapons over to the Republic, but the one addressee whom the Japanese trusted for delivery of these arms, according to the Sultan of Asahan, was he himself. He added that as a matter of fact he was on the point of personally transferring these weapons to the legal Republican authorities. But before the transfer could be accomplished his palace was suddenly surrounded, and he was forced to react in self-defense. As we have mentioned, the Sultan of Asahan was the only ruler to put up any resistance. Because his foes were too strong, he retreated, and after swimming with great difficulty across the river, he sought protection at a Japanese guard-post, which he reached safely. The Japanese military then turned him over to the Republican authorities.

To make a long story short, not much could be gleaned from research of this kind. As a matter of fact, the writer, though a reporter, never took a press card along with him or showed it around, either in the interior or in the occupied zone: it seemed that the writer's appearance was more than enough identification of his function. Nonetheless this freedom did not mean that one could safely ignore unpleasant possibilities in the sensitive atmosphere. Whispering and gossip could be pretty poisonous. Someone with a grudge from the past could easily slander one by spreading rumors, and his audience might not think twice before believing them and taking immediate action. Gossip which started out as curling wisps of smoke might suddenly become a dangerous fire--for example, gossip about the wives of civilian or military leaders wearing too many jewels could easily be associated with looted feudal treasures. A total unknown, called Logam, suddenly acquired a big reputation because he was able to spread some gossip effectively enough to stir up the public and throw harsh light on a number of high military and civilian leaders. These leaders had to undergo some highly unpleasant experiences before it was understood that Logam was being manipulated from behind the scenes by certain destructive elements. Gossip also caused the fall of several quite innocent notables, for example Police Chief $S,{ }^{59}$ and a close relative of one of the revolutionary leaders himself.

It is for this reason that the writer feels he cannot report even indubitable facts simply as he pleases. At the same time, the curious thing is something that the writer never heard of as the object of gossip or a whispering campaign: i.e., the fact that an ultra-luxurious automobile belonging to the sultan of Langkat--it was a Maybach sports-car, custom-ordered on the eve of World War II--was publicly used shortly after the "social revolution" by none other than the PKI leader, Abdul Karim Ms. himself! Once when the writer happened to be in Siantar, Karim invited him along for a ride. And indeed, aside from being very comfortable, it went like the wind. It took only six minutes to cover the fifteen kilometers from Siantar to Tiga Balata.

As has already been mentioned, Karim Ms. had accompanied Governor Hassan on his tour of inspection to the south, and he clearly had not

58. This was Mahmoed Abdul Djalil Rachmat $\mathrm{Sj}$ ah, who ascended the throne in 1927.

59. Possibly the Suleiman mentioned above. 
participated in the "social revolution." But it remained a big question how the Maybach came into his hands and was used quite openly by him. If there was one piece of feudal property which was publicly used by someone not its owner, it was this Maybach sports-car.

Rather cautiously the writer tried to ask him directly whether it was really appropriate to use such an ostentatious, luxurious object. But it seemed as if Karim already expected some question of this kind about the car. He turned the question back: "What is the use of Merdeka [Freedom] if it is not to be enjoyed? What is the significance of a Maybach by comparison with the Tsar's Palace Lenin occupied?" He went further and insisted that in a rather long drawn-out revolution like our own, what was needed was not just one Maybach, but ten, or even hundreds, "don't you know?" The writer was completely KO'd by this.

About that time the Sultan of Langkat himself was in Pematang Siantar. He was evidently not put into the VIP People's Prison at Bah Birung Ulu, but was rather boarded at the shop of a Pakistani merchant in Wilhelminastraat (now Djalan Sutomo). Since the street was very busy, and the Sultan of Langkat himself often looked out of the secondfloor windows, he was easy for people to see.

To discover how the Sultan of Langkat had managed to find shelter there was not easy either. Some unconfirmed sources stated that he had long been personally acquainted with Jakub Siregar, and that a1ready in the Japanese period he had become aware of changing times. The story went that he was more suspicious of his own circle than of the revolutionaries. In the Dutch period there had once been an attempt to kill him by poison, known to have been engineered by an aristocrat close to him whose mouth watered for his throne. As a result the Sultan had felt quite unsafe sleeping at hjs palaces in Bindjei and Tandjungpura, and always stayed at his bungalow in Manggalaan, Medan. Perhaps it was with the aid of Amir or some other influential leaders that the Sultan of Langkat managed to find safety in the marketplace of Pematang Siantar.

Nonetheless the question still remains open why he escaped, and why, on the other hand, Tengku Amir Hamzah (the celebrated national poet) was killed. 60 The writer once cautiously addressed this question to Saleh Umar who was one of the strong men of East Sumatra at that time, and who was the one man the writer believed to be a reliable source of information on these events. Without having to think twice, Saleh Umar immediately answered: Tengku Amir Hamzah's only

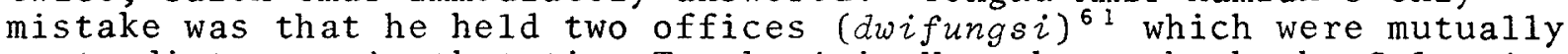
contradictory. At that time Tengku Amir Hamzah was both the Sultan's representative, and so had to defend the sultanate, and Regional Head 'Bupati) of the Republican Government for the kabupaten (regency) of Langkat, who had to join the masses, lead the revolution and at the same time defend the interests of the Republic. Nonetheless, Saleh Umar said nothing about the facts which opened Tengku Amir Hamzah to

60. Tengku Amir Hamzah gelar Inderaputra (1911-1946) was from the royal family of Langkat. He attended high school in Java, and for a time studied law in Djakarta and Leiden. In the judgment of many, he was modern Indonesia's greatest poet.

61. A phrase coined long after the revolution, usually used to describe the twin defense and socio-political roles of the military. 
charges of treason. The writer was chatting with Saleh Umar in a coffee-stall in Tebing Tinggi. Since we had known each other well since we were young reporters together, we weren't used to picking out some special place for having a chat, it didn't matter that he was by then Vice-Resident. But at that time the writer didn't simply think of having a discussion with just a poet. Like Tengku Amir Hamzah, he too was a son of Langkat.

Previously some mention has been made of the presence in East Sumatra of a Major Ferguson, a British intelligence agent, just at the moment that the "social revolution" erupted. He had been taken along on an inspection tour by Dr. Amir to Tandjung Balai and Pematang Siantar from February 27 to March 2, and was introduced everywhere as Amir's guest. The next day, March 3-4, immediately following his return to Medan, the "social revolution" broke out. In that atmosphere it was reported that Resident Junus Nasution was out of town to check out on the spot the outbreak of the "S.R." But that same week it was also reported that Ferguson had gone along as a member of Junus Nasution's party to Langkat, an area which also had experienced the antifeudal hurricane.

Because Ferguson was present at the moments that the affair occurred, he naturally became an object of suspicion, irrespective of whether facts could or could not be produced to raise the suspicions to the level of accusations. Dr. Amir himself, the Vice-Governor who had given him so many facilities for moving about in de facto Republican territory, could not escape suspicion either. It is not impossible that Amir and Ferguson were working together. People got this impression from the lact that not long afterwards Amir fled to the Allied camp. There is no convincing indication, let alone proof, that either Amir's life or his family's were in any danger. From a very close relative of his, Adinegoro, the writer heard that Dr. Amir was driven by his Dutch wife to choose: either continue serving the Republic or by joining his wife and children who were determined to return to the Moederland [motherland]. Dr. Amir chose the second alternative. In the midst of all this pressure, it seemed, however, that Amir still wanted to play a role by dragging things out, and that was why he ok'd, signed or granted whatever any particular leader urged on him, while he still had the opportunity, i.e., while Governor Hassan was still on his inspection tour to the south. It turned out that Amir had been making plans to flee to the Allied camp for a long time. Whether or not he was helped in this by Major Ferguson is something which badly needs to be demonstrated, if we want to unmask Ferguson's involvement in the chaos that raged at that time. On April 23, Allied troops were put on guard at Dr. Amir's house in Djalan Bulan 16. Only on the following day did he flee to the camp, where he could rest easy under the protection of the Gurkhas.

The writer has tried to dig up more information about Ferguson, but without success. It is quite common for men like him, who have been eye-witnesses of extraordinary events, to talk about them or write up their reminiscences in an article or a volume of some sort. For example, Major Knottenbelt, whom we have mentioned as being in Kutaradja at the beginning of the revolution, described his impressions in Vrij Nederland (January 14, 1946). It is quite likely that Ferguson did the same, and from the truth or falseness of his version. . . . ${ }^{6}$

62. This sentence is incomplete in the original Indonesian, probably by a printer's error. 
Once, on a visit to London, the writer took the opportunity to go to the British Museum and look for Ferguson's name in the authors' index, but did not find it. But the writer did on that occasion have the good luck to get acquainted with Prof. Gardner, curator of the Southeast Asian section of the Museum 1ibrary. He introduced himself to the writer as a British private in a squad which was attacked by the Lasjkar Rakjat [irregulars] at Brastagi, Tanah Karo, in October 1945. Gardner described to the writer in some detail his being wounded while his unit was driving in jeeps up the last steep slope into Brastagi. He fell, but was rescued by civilians and was taken to the local Japanese military post; from there he was taken back to safety in Medan.

It is very likely indeed that Major Ferguson sent in a secret official report on the "social Revolution" in East Sumatra to his superiors, whether to Lord Mountbatten, who had by then moved his headquarters from Kandy to Singapore, or directly to the Foreign Ministry in London. If some such report exists, perhaps it will only be possible to read it when the "secrecy" period for such documents is over.

So it can be said that the writer was not very successful in learning any more data and facts about the "social revolution" than what has been laid out above. But perhaps the above notes may have some use in opening the way to acquiring further information.

\section{A Confession}

At the beginning of May 1950 the writer was chosen by the PNI conference as First Chairman/North Sumatra, even though the writer was actually still a "newcomer," in fact had never been registered as a party member. Because the election took place in the writer's absence, the writer accepted it respectfully and with appreciation, especially after learning that the vote had been unanimous. After that the writer was active in leading the North Sumatra PNI up until 1954. The three-point urgency program of the PNI of North Sumatra at that time was enough to give anybody a headache:

1) Defend the rights of the peasants to the land they cultivate on concession 1 and, who, by the terms of the Round Table Conference can not be summarily evicted without their consent;

2) Demand the nationalization of the BPM oil-wells in North Sumatra; and

3) Demand the release of PNI political leaders in detention.

These three questions all escalated into national issues, the most controversial being peasant-cultivated land, which culminated in the celebrated Tandjong Morawa Affair. ${ }^{63}$ The demand for the nationalization of BPM was no less heated an argument, to the point that it seriously exacerbated conflict between the PNI and Masjumi. The Masjumi obstinately insisted on immediately returning the oil-wells to

63. For details on the 1953 Tandjong Morawa Affair, in which five peasant squatters who resisted eviction were killed by the police, see Herbert Feith, The Decline of Constitutional Democracy in Indonesia (Ithaca: Cornell University Press, 1962), pp. 294-296. 
their respective concessionaires. ${ }^{64}$ In the end, the result came close to the demands of the North Sumatra PNI, and if today we have a large state oil company called Pertamina, don't forget that its origin way back was the demands and decisions of the North Sumatra PNI.

As for the third issue, the release of PNI leaders, among those who made direct contact with the writer by letter were: (1) Saleh Umar (comrade-in-arms/partner of Jakub Siregar); and (2) Selamat Ginting.

Saleh Umar had been detained because of the security situation and because jewels seized from the feudal groups were found in his hands. Many efforts were made on the two men's behalf, and on one occasion both were released, only to be re-arrested two days later at the orders of Col. Simbolon ${ }^{6}$ (just as Saleh Umar and Jakub Siregar were about to take the plane for Djakarta). It was only much later on that they were finally released without ever being brought to trial. Their case was dideponeerd (permanently closed).

With regard to the security issue, it seems as if this was connected with the behavior of the Barisan Harimau Liar, of which the two men were known to be the prime leaders. Since the BHL business was also rather closely related to the activities of the Japanese Kempeitai figure Captain Inouye, whom the Allies had classified as a war criminal, and since their practices were reported to be very cruel, the Allies paid special attention to them. The writer yot this impression from a meeting with Stan Swinton, an American reporter for the Associated Press, who was covering the development of the cease-fire [at the time that] the Three-State Commission visited Medan in September 1947.65 Swinton gave the writer a copy of a cable he was about to send from Medan to New York, and gave permission to print it in the newspaper Waspada which the writer ran at that time. In this report he stated quite categorically that on the eve of the Allied landings the BHL had been formed by Captain Inouye, its troops consisting of we11-trained Indonesian pemuda, with the aim of slowing down and obstructing the Allied landings. In his report Swinton stated that he had obtained his information from a Major-General in the TNI (Army), 67 who told him that the BHL also opposed the Republic and so had to be dealt with. Its initial strength was 2,000 fully armed men, and it had detained 3,000 people, all in all, including 500 Chinese (Tionghoa).

With regard to the jewels in Saleh Umar's hands, so far as the writer could discover from Saleh's own comments and from the information that went around, it is clear that when, at the beginning of 1950 , Saleh Umar was given the opportunity by Kawilarang to bring the in to

64. For details on the politics of this issue, see ibid., pp. 298, 301 and 411 .

65. Col. Maludin Simbolon was Panglima (Military Commander) of TT/I (North and Central Sumatra) from April 1950 to December 1956.

66. The Three-State Commission (Belgium, Australi. and the United States), often referred to as the Committee of Good Offices, was set up by the U.N. Security Council in August 1947 following the first Dutch military action against the Republic.

67. In 1947, the name of the Republican Army was changed from TRI to TNI (Tentara Nasional Indonesia--Indonesian National Army). 
Medan before going to prison, all were surrendered to the Panglima with a full inventory and signed receipt. ${ }^{68}$ The whole question was tied in with the role of A. E. Saragih Ras, as will be described below.

With respect to the notable Selamat Ginting, the issue was quite separate. ${ }^{69}$ It seems that when the Round Table Conference Agreement was accepted, he did not believe in the good faith of the Dutch. Before going back into the city [Medan], Selamat ordered his men to bury all their weapons. He calculated that if the Dutch launched a third attack, it would not be difficult to reactivate the resistance. He was arrested at Simbolon's orders, and after a long period in prison, was brought up for trial. Evidently the judge understood that he had had no evil intentions towards the Republic and the government, but still he was sentenced, though only for the duration of his pre-trial detention.

The writer felt that his party's mission to win the release of the PNI's prime leaders was done, when suddenly he received a further letter from still another PNI leader. This was A. E. Saragih Ras, active commander of the Barisan Harimau Liar himself, who wrote to ask the writer's help to get released from prison. It seemed that he had been held for more than a year, since being surrounded in Simelungun by Mobrig, who had been hunting him down for a long time. ${ }^{70}$

When the writer went to visit him in the jail at Pematang Siantar, he found himself face to face with an extremely emaciated and exhausted man (whose physical and mental condition had deteriorated bad1y). The writer could not stop wondering how such a man could control and keep tight discipline over a large force of pemuda, forming a much feared unit.

Saragih Ras had not had an easy youth, by any means. The writer got this impression from the written autobiography Ras gave him. He began to make his own living when he was sixteen as the driver of an ox-cart. In 1922 he became a leerlingsschrijver (apprentice clerk) in the office of the Panei administration (Simelungun). He resigned in 1923, joined a gang of smugglers, and became a gambler as well. In 1924-1925 he studied magic with the Persatuan Pentjak Natal [Natal Pentjak Association]. In 1926 he worked in a garage and succeeded in getting a driver's license. From 1927 to 1930 he was a taxidriver. From 1931 to 1941 he was acting chief of Kampung Saragih Ras and a member of the Kerapatan (Adat) Court for twelve years--as well as

68. Co1. Alex Kawilarang was Panglima of TT/I from December 27, 1949 (the transfer of sovereignty) till April 19, 1950, when he was relieved by Simbolon.

69. Selamat Ginting was born in 1923 in Kuta Bangun, Tanah Karo. He made his reputation as a pemuda military leader during the revolution--first as commander of the Lasjkar Rakjat irregulars in Medan and Tanah Karo; then as commander of Napindo (Nasional Pelopor Indonesia--Indonesian National Vanguard) for North Sumatra--concurrently Napindo field commander in the Medan area and leader of the Napindo Halilintar (Lightning) Regiment; finally as commander of Sector III/VII and acting military governor of Dairi. He resigned from the military after the transfer of sovereignty over the demobilization issue, and became an important PNI leader in the Karo region.

70. Mobrig--Mobil Brigade--the crack motorized force of the Indonesian police (later known as Brimob). 
being clerk of the collection office in Tiga Ras and a contractor for the plantations. In 1938 he became a member of the Pematang Siantar branch of Gerindo and founded the Tiga Ras sub-branch. In 1942 he actively welcomed the Japanese. In 1943 he ran the Tiga Ras trading cooperative in agricultural products and was head of the local Peasant League (Sarekat Tani). In 1944 he became a member of the Kenkoku

Teisintai (Barisan Harimau Liar) formed by Inouye, and in 1945 led the Barisan Harimau Liar formed from former KT elements.

Saragih Ras stated that his forces had at one time attained a strength of twelve battalions. As a disciplined commander, Saragih Ras was in turn fully obedient to his superiors, i.e., the duumvirate Saleh Umar-Jakub Siregar. Given this complete obedience, it was not surprising that the Sumatra Commander, Major-General Suhardjo, once assigned Jakub Siregar to form, along with five other leaders (Lt. Col. Kartawinata, Bustami, Amir Jusuf, Selamat Ginting and Bedjo), a TNI strike-force consisting of picked pemuda, a fact which gives one the impression that the Barisan Harimau Liar itself was expected to be the core of this new force. ${ }^{7}$

The further details of Ras's life were quite lengthy and are not relevant to this article except for his story or confession about the history of the feudal treasures (including cut and uncut diamonds) which at one point were in his hands. He explained this to the writer along the lines of what he had told the High Military Prosecutor and the Deputy Prosecutor-General from Djakarta when he was interrogated.

Saragih Ras stated that about eight days before the "social revolution" broke out, he received secret instructions from the Supreme Headquarters leaders in Medan who came specially to Siantar for the purpose. The meeting was held in the former Simelungun Club building. Saragih Ras stated that the visitors from the Supreme Headquarters Command consisted of Sarwono, its general chairman, and Zainal Baharuddin, its secretary. On that occasion Sarwono stressed that it was now quite clear that the rulers and their henchmen were an obstruction to independence: Therefore, said Sarwono, a revolution would have to be carried out to crush them and their major henchmen. A lengthy discussion then followed and finally Saragih Ras steeled himself to undertake the mission to carry out the "revolution," a mission he received via the top leadership of the Barisan Harimau Liar, i.e., Saleh Umar himself. The same mission was assigned by Sarwono directly to a certain Aziz Siregar, a Pesindo leader in Simelungun. The execution of the mission, said Saragih, was done starting at 00 hours March 3-4, with the understanding that action be taken in each kampung by the local kampung men themselves. Further, Saragih accompanied Saleh Umar on a tour round other kampung in Simelungun to assign similar tasks in the relevant places. In Tanah Djawa, said Saragih, the task was assigned to Bagus Saragih, the head of the PKI in Tanah Djawa.

Saragih Ras related that the missions were carried out successfully, but that on that occasion no seizure of jewels was made. Nonetheless, it later turned out that some jewe1s did come into his hands. In this regard he stated that in 1949 he turned all this property over

71. Major-General R. Suhardjo Hardjowardojo had been appointed the top Army commander for all of Sumatra in June 1946. (He had been police chief in Lampung before that.) He was recalled to Jogjakarta only on the eve of the second Dutch military attack. 
to Saleh Umar in his then capacity as Vice-Resident of East Sumatra, via the Commission which they had set up. This was done so that ali the property might be officially transferred and received in the public view. He added that on two occasions part of the jewels had been used. First, to buy supplies in Sidikalang with a receipt from the above-mentioned Commission. Second, when they were in Pasar Matonggar, South Tapanuli, in order to buy weapons in Singapore. Again a receipt existed as evidence; the man who arranged the purchase was Saleh Umar, and he in turn assigned a Chinese called Oei Boen Tjoan to carry it out.

So much for a small fragment of the quite lengthy narrative/confession of Saragih Ras. From this narrative/confession of his it turns out that the "social revolution" was a secret project of the Supreme Headquarters and that the leadership of the Supreme Headquarters was Sarwono and Zainal Baharuddin, with Saleh Umar as an associate. What the status of the Supreme Headquarters was vis-à-vis the Volksfront, and whether it in effect was the military section of that joint body, is not clear.

Likewise, Saleh Umar himself, as a matter of fact, gave an accounting for the feudal treasure that he said was once in his hands. Some years later, after the whole business seemed to have been gedeponeerd, Assistant Prosecutor-General Muthalib Moro came to Medan to return the treasure which had been handed in to the aristocrats who claimed to be the owners. The transfer was carried out in a room at the Prosecutor's Office in Medan, and the ceremony was made open to journalists as witnesses.

So far as could be seen, the affair seemed closed, although in actual fact a great deal of the feudal treasure had disappeared to who knows where. Even though some people must have known, evidently they were keeping it quiet. Up till now, there seems to have been no more attention paid to that part of the treasure which was not in Saleh Umar's hands.

Just for the record: not long after the first Dutch aggression, Pematang Siantar was occupied by Dutch troops, and so the capital of Sumatra had to be moved to Bukittinggi. Among those who moved with it were seconded Resident Abdul Karim Ms. and other intimate Karimists such as S. M. Tarigan, Sarwono, Mr. Luat Siregar and of course Jahja Jakub, who continued actively running the All-Sumatra office of Information (under the Governor), though there was a Ministry of Information representation for Sumatra as well under the leadership of Adinegoro.

At the time of the election of the KNIP [Central Indonesian National Committee] prior to the second Dutch aggression, as a result of Karim's efforts, Mr. Luat Siregar was chosen, and he also became a member of its Working Committee. So too was Zainal Baharuddin. Sarwono followed later--with the result that those leaders who evidently knew most about the ins and outs of the "social revolution" were now in Java. Junus Nasution, whom we last saw in Raja, popped up in Mandailing shortly after the first [Dutch] aggression, and from then on was active in South Tapanuli only. He knew nothing of what had happened to the feudal treasure.

Thus, if the development of the "social revolution" is to be organized into a coherent body of notes and commentary from $A$ to $Z$, much more time and cautious patience will be required. For aside from 
developments within Republican territory, there was also an important court case during the Dutch occupation period. Information from that source could in some way be compared with developments elsewhere, so that the data and facts could be properly fitted together and organized, even though as things stand now the whole affair seems to be a long chapter without a conclusion. Finis!!!! 